POLIIICAL ECONOMY RESEARCH INSIITUTE

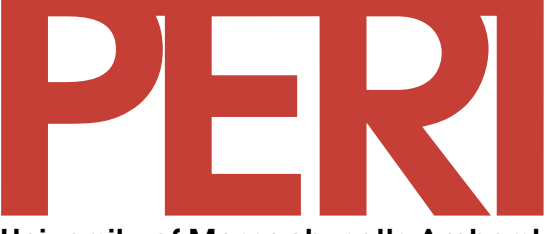

University of Massachusetts Amherst

\title{
Capital Flows, Capital Account Regimes, and Foreign Exchange Rate Regimes in Africa
}

\author{
Léonce Ndikumana
}

2003

10th floor Thompson Hall University of Massachusetts Amherst, MA, 01003-7510 Telephone: (413) 545-6355 Facsimile: (413) 545-2921

Email:peri@econs.umass.edu Website:

http://www.umass.edu/peri/

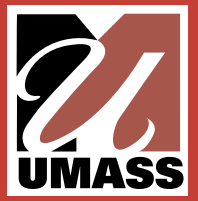




\title{
Capital Flows, Capital Account Regimes, and Foreign Exchange Rate Regimes in Africa
}

\author{
Léonce Ndikumana \\ Department of Economics \\ University of Massachusetts, Amherst, MA 01003 \\ Tel: (413) 545-6359;Fax: (413) 545-2921 \\ Email: ndiku@econs.umass.edu; Web: http://www-unix.oit.umass.edu/ ndiku
}

\section{This draft: February 2003}

Acknowledgements: The original version of this paper was prepared for a project of the United Nations Conference on Trade and Development (UNCTAD) and presented at the workshop on "Management of Capital Flows: Comparative Experiences and Implications for Africa" held in Cairo on March 20-21, 2001. The author is grateful for constructive comments from Kamran Kousari and S.C. Kasahara. The author alone is responsible for any remaining errors as well as the views expressed in this paper. 


\begin{abstract}
This study examines capital flows and shifts in capital account and exchange rate regimes in African countries over the past two decades. The evidence shows that official lending to Africa has declined while the volume of private capital flows remains low and significantly below the levels observed in other developing regions. Private capital inflows to Africa are limited due to several factors, including the weakness of the macroeconomic environment, underdeveloped financial systems, high country risk, and exchange rate misalignments. The focus of policy reforms must be on alleviating these constraints in order to attract more foreign capital and overcome the shortage of development financing.

Many African countries have pursued reforms aimed at liberalizing their capital account and exchange rate regimes. However, liberalization has not been accompanied by systematic gains income growth, price stability, and trade performance. African countries must pay serious attention to the scope, speed, and sequencing of capital account liberalization to minimize potential adverse effects of openness. It is desirable for countries to maintain selective discretionary control over capital movements and exchange rate markets in order to hedge against adverse shocks to the economy and to maintain macroeconomic and financial stability. To attract foreign capital, any move toward capital account openness and exchange rate liberalization must be supported by reforms aimed at improving credibility of macroeconomic policy and establishing an investment-friendly environment. These reforms will not only attract foreign capital but also encourage domestic investment.

An important aspect of capital movements in Africa is the high level of capital flight. There is an urgent need for policies to stem further hemorrage of capital from Africa and induce the repatriation of private capital held abroad. This will require not only improvement of the macroeconomic conditions to ameliorate incentives for domestic investment, but also reform of the political and legal systems to improve accountability and credibility of economic policy.
\end{abstract}

JEL Classification: F21, F32; O55 


\section{Introduction}

Until recently, the economics literature paid relatively little attention to international private capital flows to Africa, with most of the discussion focusing on official aid (Kasekende et al 1999). Recent studies have important empirical and policy issues associated with private capital flows to Africa, but research in this area is still severely constrained by the scarcity of data. The existing data on capital flows to Africa are fragmented and inconsistent, which makes it difficult to assess the nature, the term structure (long-term vs. short term), and the sectoral distribution of foreign capital (Bhinda et al 1999). As a result, it is still difficult to formulate consistent policy recommendations.

This study investigates a number of issues related to capital account regimes in Africa over the past two decades. First, recent studies have pointed out a "surge" of private capital inflows to Africa, especially in the 1990s (Bhinda et al 1999). However, the volume of private capital flows is still small relative to domestic capital formation. Unlike in other developing regions, private capital flows to Africa have not increased enough to offset the recent decline in grants and official lending. This study discusses some of the factors that constrain private capital inflows to African countries.

Second, to varying degrees, African countries have pursued liberalization of their capital accounts. In some countries, capital account transactions have been fully liberalized (see Appendix). However, liberalization has not been accompanied by improvement in macroeconomic performance. The economic situation in some countries (such as Kenya) has actually deteriorated under liberalization due to excessive speed and poor sequencing of liberalization. While liberalization can attract international capital, 
the process can also have adverse effects on the economy in the presence of structural macroeconomic imbalances.

Third, the exchange rate regime shifts around the world have been characterized by a "hollowing out" of the middle of the exchange rate regime spectrum, where countries are moving from intermediate exchange rate regimes (pegged but managed, or 'soft pegs') to either hard pegs or independently floating exchange regimes. For African countries, however, the transition has been asymmetric, mostly involving countries moving from soft pegs to independently floating regimes with virtually no movement from soft to hard pegs. Most countries still have a relatively weak economic base, underdeveloped financial systems, and a weak regulatory environment. Given these conditions, the transition by African countries to independently floating exchange regimes is puzzling.

Fourth, the establishment of the European Monetary Union and the adoption of the euro as the common currency in most of Europe have rejuvenated the debate over currency regimes. Some scholars have suggested that given the increasing globalization of finance and trade, countries should abandon exchange rate management and adopt a strong currency as legal tender (see Berg and Borenzstein 2000; Calvo and Reinhart 1999). For African countries, this could involve dollarization or - with the creation of the euro - euroization, and possibly also the adoption of a strong African currency (e.g., the rand) or a regional currency. This study discusses the benefits and costs that such a regime shift would imply for capital mobility and macroeconomic stability.

Fifth, an important aspect of capital movements in Africa is the high level of capital flight. According to recent studies, Africa as a region has the highest proportion 
of private assets held abroad (as a percent of total assets or GDP) compared to other developing regions (Collier, Hoeffler and Pattillo 1999). Capital flight is pervasive in the severely indebted low-income countries, which at the same time are overburdened by high levels of debt (Boyce and Ndikumana 2001; Ndikumana and Boyce 2002). Capital flight imposes high costs on African economies and must be regarded as an urgent matter of concern. Capital flight can be interpreted as the outcome of portfolio choice as private actors seek to maximize returns on assets and minimize risk by holding their assets abroad. Capital flight can also arise through illegal acquisition and use of national resources for private enrichment by private individuals and public officials. Controlling capital flight will require not only improvement of the macroeconomic conditions to ameliorate incentives for domestic investment, but also reform of the political and legal systems to improve accountability.

The remainder of the paper is organized as follows. Section 2 presents the trends and patterns of capital flows to Africa over the past two decades and discusses the constraints to private capital inflows. Section 3 highlights recent reforms of capital account regimes and discusses motivations for capital account restrictions in Africa. Section 4 discusses exchange rate regime transitions and the implications for capital mobility and economic performance. Section 5 examines the motivations, advantages, and disadvantages of dollarization for African countries. Section 6 presents some estimates of capital flight and discusses the conduits, causes, consequences of capital flight, and implications of capital account liberalization for capital flight. Section 7 summarizes and discusses some policy implications. 


\section{Capital flows: Recent trends and patterns}

\section{a. "Surge" in FDI in Africa: an illusion?}

From 1990 to 1999, private net resource flows to all developing countries increased almost six fold, from $\$ 42$ billion to about $\$ 239$ billion (Global Development Finance 2000). Private capital flows have increased substantially, bypassing official capital flows. This "surge" in private capital flows to developing countries has been interpreted as a byproduct of global financial integration (World Bank 1997). International investors penetrate markets in the developing world in search for higherreturns investment opportunities as well as a way of minimizing risk through portfolio diversification. At the same time, recent economic reforms undertaken by developing countries have contributed to attracting private capital (Singh 1999; Singh and Weisse 1998). Financial integration is supposed to benefit developing countries by allowing them to tap the pool of global capital and achieve higher economic growth through improved resource allocation through financial markets (Fischer 1999).

At first glance, capital account movements in Africa share some similarities with these global trends. The volume of foreign direct investment (FDI) has increased substantially over the past decade. Annual FDI inflows to Africa, excluding South Africa, increased from an average of $\$ 1.2$ billion in the $1981-1985$ period to $\$ 2.9$ billion in 1986-1991, and \$5.3 billion in the 1992-1998 period (UNCTAD 1995, 1998, 2000). However, from a closer look, the recent increase in FDI inflows in Africa is not as substantial as it appears. 
FDI increase: not as extraordinary as it appears

The apparent extraordinary increase in FDI inflows to Africa appears illusory. The volume of FDI inflows to most African countries was extremely low until the early 1980s (Table 1). For example, FDI inflows increased from $\$ 0.2$ million in 1981-85 to $\$ 125$ million in 1992-98 in Zimbabwe, from \$19 million to \$108 million in Zambia, and from \$8.5 million to \$107 million in Ghana. However, the appearance of a "surge" in FDI is only due to the fact that the initial levels were very low.

Moreover, FDI still makes a relatively small contribution to capital formation in African countries. In the 1992-1998 period, the ratio of FDI inflows to gross domestic investment is less than $10 \%$ for 30 out of the 41 countries in the sample in Table 1 (excluding countries with missing data) and less than 5\% for 17 countries in the sample. The noticeable exceptions are Nigeria, Seychelles, and Zambia where the ratio is over $20 \%$ and Angola and Lesotho, with ratios over 30\%. These countries also have high gross investment rates. The gross domestic investment to GDP ratio for the 1992-98 period is $23 \%$ for Angola, $77 \%$ for Lesotho, and 39\% for Seychelles (World Development Indicators 2000). Shrinking share of FDI in Africa among developing countries

Africa's share in total FDI inflows to developing countries has declined since the second half of the 1980s, even as the absolute volume was increasing (Figure 1 and Table 2). In 1999, sub-Saharan Africa received only 4.3 percent of total FDI inflows to the developing world, down from an average of $10.5 \%$ in the $1981-1989$ period. It is clear that Africa has not substantially benefited from this global increase in capital flows as much as other developing countries. The low levels of FDI to Africa cannot be fully 
explained by rate of return considerations. Rates of return to FDI in Africa are

comparable to or even higher than those in other developing regions (Figure 2).

The changing distribution of FDI across the continent

FDI inflows to Africa have traditionally been concentrated in extractive industries.

The top 10 beneficiaries of FDI inflows accounted for 82 percent of total FDI inflows to Africa (excluding South Africa) in the 1992-1998 period (Figure 3). Oil exporters have been the primary beneficiaries of FDI inflows, but their share has declined over the years. In the second half of the 1980s, the group accounted for 70 percent of total FDI inflows to Africa. The ratio was just $59 \%$ in the 1990 s.

While the initial drive of FDI inflows to Africa was the extraction of primary resources, especially oil and mines, the motivation for foreign capital seems to be changing slowly. Capital inflows are low, stagnating, and even declining in some oil exporters, such as Cameroon, Congo, and Gabon (Table 3). At the same time, some "new comers" are attracting increasing attention from international investors (Figure 4). Noteworthy cases are Mozambique, Tanzania, Uganda, Zambia, and Zimbabwe. These are also among the African countries that have made significant progress in economic policy reforms over the last decade, which have contributed to price stability, fiscal discipline, improvement of the economic infrastructure, and the creation of a better environment for private investment. There is also evidence that the returns to investment in extractive sectors are not higher than in the manufacturing sector (Figure 2), which may partly explain the increasing sectoral diversification of FDI. 


\section{b. Other capital flows to Africa}

Private capital flows to developing countries have increased significantly relative to official capital flows over the last two decades. The share of private capital flows in total net resource flows to all developing countries increased from $58 \%$ in 1980 to $82 \%$ in 1999. By comparison, over the same period, the ratio for sub-Saharan Africa (SSA) increased only slightly from $37 \%$ to $41 \%$ (Figure 1 ).

The volume of official capital inflows to SSA has also decreased since the 1980s. Net long term lending has declined both in absolute volume as well as a share of total net lending to all developing countries. SSA's share in grants has slightly declined although not as markedly as long-term lending. The decline in official long-term lending and grants has not been compensated by any increase in private lending. Sub-Saharan

Africa's share in long-term lending to developing countries declined from $17 \%$ in 1989 to just 3\% in 1999. The increase in FDI in Africa over the recent years is lower compared to other regions, while other private capital flows such as equity portfolio investment have in fact declined after reaching a peak in 1995 (Figure 1 and Table 2). In 1999, portfolio equity investment in SSA was only $\$ 492$ million in nominal terms compared to \$1.1 billion for South Asia and \$3.6 billion for Latin America and the Caribbean (Global Development Finance 2000). After increasing substantially from 1992 to 1995 (from $\$ 153$ million to $\$ 4.9$ billion in constant 1995 dollars), the volume of portfolio investment in SSA has declined sharply since. Private net resource flows declined from 1980 to 1990 and increased thereafter while official net resource flows declined. This resulted in a significant increase in the share of private net resource flows in total resource flows (Figure 1). 


\section{c. Constraints to private capital inflows in Africa}

There are many constraints to the expansion of private capital inflows in Africa, including the weakness of the macroeconomic environment, underdeveloped financial systems, high country risk, and exchange rate misalignment.

\section{Weak macroeconomic environment}

The weakness of the macroeconomic environment in African countries is a result of a range of factors, including low resource endowment, exogenous shocks, and misguided macroeconomic policies that have accentuated the adverse effects of exogenous shocks. Economic performance has been dismal in many countries, especially since the 1980s (see Collier and Gunning 1999a, 1999b). However, evidence shows that countries that have consistently pursued economic reforms aimed at redressing economic imbalances have experienced an improvement in economic performance, which has increased investor confidence. This may explain the recent increase in foreign capital inflows in countries like Mozambique, Tanzania, Uganda (see Table 3).

\section{Underdeveloped financial systems}

The level of sophistication of the financial system is an important determinant of both the ability of a country to attract international capital and the ability of the financial system to withstand shocks to global capital flows. With the exception of a few countries (South Africa, Egypt, Morocco, and probably Kenya, Mauritius, and Nigeria), most African countries have underdeveloped financial systems. ${ }^{1}$ The following features are especially worth emphasizing:

\footnotetext{
${ }^{1}$ For further discussion of financial development in Africa, see Ndikumana (2001), Gelbard and Leite (1999), Nissanke and Aryeetey (1998), and Mehran et al. (1998).
} 
- Size and depth: In most African countries, financial systems are still shallow. With the exception of South Africa, African financial markets offer a limited range of financial products. Bank lending is predominantly short term, government securities are mostly of short maturity, banks in many countries do not issue credit cards (issued in only 15 sub-Saharan countries in 1997), and inter-bank lending is still underdeveloped (Gelbard and Leite 1999).

- Low stock market development: The majority of African countries do not have active stock markets, and most of the active stock markets are still small and illiquid, including long-established stock markets, such as the Egyptian Stock Exchange (Ndikumana 2001).

- Poor performance: African banking sectors are still characterized by inefficiencies in credit allocation and poor loan repayment enforcement mechanisms, which result in high proportions of non-performing loans. Gelbard and Leite (1999) report an average share of non-performing loans of over 20 percent in a sample of 38 subSaharan countries in 1997.

- Weak regulatory and supervision framework: The institutional environment for financial development is still inadequate in many African countries. Some of the basic requirements for effective banking supervision (e.g., modern banking laws, central bank autonomy) and prudential regulation (e.g., establishment and enforcement of minimum bank capitalization ratios, deposit insurance) are still nonexistent in many countries (Gelbard and Leite 1999; Mehran et al 1998; Nissanke and Aryeetey 1998). 
In the context of adjustment programs, some countries have made significant progress in reforming their banking systems. In particular, countries are establishing new banking laws or reforming existing ones to improve supervision and prudential regulation. Moreover, the participation of the state in the banking sector has decreased as a result of the privatization of state-owned banks and the easing of licensing requirements, which have accelerated the creation of new private banks. To the extent that these reforms are supported by market friendly macroeconomic policies (especially fiscal discipline and non-inflationary monetary policy), they will enhance investor confidence and attract more foreign private capital.

\section{High country risk}

Africa has traditionally been considered as being "atypically risky" and a "capitalhostile environment" (Collier and Pattillo 2000: 3). Surveys reveal that, in the opinion of investors (foreign as well as local), the most important obstacles to investment are fear of political instability and the risk of policy reversal. Weak and volatile macroeconomic fundamentals also contribute to high country risk. These include high and variable inflation rates, exchange rate instability, and chronic fiscal deficits. Another important factor of high investment risk in Africa is effective distance as perceived by international investors, which is influenced by geographic distance, transactions costs, and cultural/psychological distance. African countries can improve their risk ratings through sustained economic reform. It should be noted, however, that international rating agencies tend to rate Africa as being riskier than is warranted by objective conditions (Haque et al. 2000). As a result, the impact of economic reforms on risk rating for a particular country may be retarded by a "bad neighborhood" effect. 


\section{Capital account regimes: openness and related issues}

\section{a. Recent developments in capital account policies}

Towards greater openness

In the context of the macroeconomic reforms initiated in the 1980s and

accelerated in the 1990s, many African countries have moved towards greater capital account openness by abolishing or relaxing existing capital controls. The text in the appendix and Table A2 contains a summary of important recent reforms for some countries. The following is a non-exhaustive sample of recent reforms in the current account regimes.

- Limitations to foreigners' participation in domestic investment have been relaxed and even abolished in some countries. However, governments have maintained controls in strategic sectors, like crude oil and gas in the case of Nigeria.

- Countries have relaxed or abolished restrictions on nonresidents' ability to repatriate dividends, interest income, as well as proceeds of sales or liquidation of the initial investments.

- Investment by residents in foreign-currency denominated assets locally and abroad is now allowed in a number of countries. However, even in countries with relatively liberal regimes, some limitations are maintained for strategic reasons. For example, in South Africa, the government maintains a limit on the amount of investment abroad by residents. Corporations can invest up to R250 million within the SADC region (no limits for Lesotho, Namibia, and Swaziland) and R50 million elsewhere. 
Institutional investors are allowed to invest abroad up to 15 percent of their assets, while the maximum allowed for individuals is R750,000.

- Recent reforms have allowed nonresidents to purchase stocks and government securities. Kenya and South Africa are the leading reformers in capital account liberalization.

\section{Liberalization in the context of regional arrangements}

Liberalization of capital account regimes has also accelerated in the context of new or existing regional arrangements. With the exception of the CFA zone, which is an integrated monetary union, African regional arrangements have traditionally emphasized trade integration. Recently countries have pursued greater capital mobility . A noteworthy example is the Cross-Border Initiative in Eastern and Southern Africa (CBI) (see Fajgenbaum et al 1999). However, in the case of overlapping regional arrangements, economic incentives can be distorted when obligations under the various bodies are inconsistent. For example, it is not clear how countries that belong to both the CBI and the SADC can reconcile discrepancies in tariff arrangements since some of these are different in the two bodies. Harmonization of obligations across regional entities is necessary to allow countries to take full advantage of regional integration.

Scope, speed, and sequencing of liberalization

Three important points are worth emphasizing with respect to recent capital account liberalization in Africa. First, despite the visible trend towards liberalization there is still a wide diversity in capital account openness across the continent. Some countries have very open capital accounts, such as Kenya and South Africa, with few restrictions on FDI and other capital account transactions by individuals and firms. In 
other countries, transactions are tightly controlled, including restrictions based on the sectoral allocation of FDI (see Table A2).

Second, countries must pay serious attention to the scope, speed, and sequencing of capital account liberalization to minimize potential adverse effects of openness. Evidence shows that speedy liberalization results in macroeconomic instability, generating effects that are opposite to the intended objective of liberalization. Kenya is a compelling example on this issue. Facing imminent crisis at the end of the 1980s, the Kenyan government embarked on an aggressive reform agenda including the opening of the capital account and liberalization of the foreign exchange market. However, the crisis continued throughout the 1990 s, as a result of severe macroeconomic imbalances.

Capital account liberalization ultimately increased the country's vulnerability to fluctuations in capital flows, especially by providing 'legal' channels of capital flight (Ariyoshi et al. 2000: 67).

Third, to attract foreign capital, capital account openness must be supported by broad-based macroeconomic reforms aimed at improving the investment environment. Countries must especially pursue fiscal discipline, responsible monetary policy committed to price stability, ${ }^{2}$ and institutional reforms aimed at fostering a legal and regulatory environment that is conducive to financial intermediation. There is evidence that countries that have made progress in economic and institutional reform and improved credibility of macroeconomic policy are also attracting the attention of international investors.

\footnotetext{
${ }^{2}$ Commitment of monetary policy to price stability does not necessarily amount to surrendering the right of national authorities to use monetary policy to respond to exogenous shocks. The idea is to foster disciplined discretion in monetary policy, especially by shielding monetary policy from fiscal pressures.
} 


\section{b. Motivations for capital account restrictions in Africa}

Why liberalize the capital accounts?

Proponents of capital account liberalization have advanced two main arguments in favor of liberalization (Fischer 1999). The first argument is that capital account liberalization is an "inevitable step on the path of development which cannot be avoided and should be embraced" (Fischer 1999: 2). Historical evidence demonstrates, so the argument goes, that the most advanced economies have open capital accounts. The second and arguably more powerful motivation for capital account liberalization is that the potential benefits of liberalization outweigh the costs. Potential benefits include increased access to a larger and more diversified pool of funds by investors (local and foreign), resulting in higher opportunities for portfolio diversification.

However, even proponents of capital account liberalization acknowledge important risks associated with liberalization (Fischer 1999: 2-3). International capital flows - especially short term capital - tend to be highly volatile and capital reversals are costly. Capital markets tend to react erratically following shocks to the economy. Through contagion and spillover effects, capital market shocks tend to spread quickly across countries, often irrationally, reflecting herd behavior. The risks associated with capital account openness are particularly high for countries with weak macroeconomic fundamentals, underdeveloped financial systems, and poor banking regulatory institutional infrastructure. African countries should therefore exercise great caution in liberalizing their capital accounts. 


\section{Capital controls vs. capital restrictions}

The literature on the management of international capital flows has focused primarily on the desirability and the effects of capital controls. However, as Cooper (1999) points out, capital controls are a subset of a larger set of policy options for managing international capital flows. Capital controls are typically quantitative limitations on capital flows. There are, however, administrative and price penalties on capital movements that may have similar effects as capital controls. These include differential reserve requirements on assets and tax preferential treatment of certain categories of capital deemed favorable for economic growth (such as FDI as opposed to short-term portfolio equity investment). Therefore, countries have more than the option of imposing or not imposing capital controls. They can also select and sequence various strategies in order to manage the volume and distribution of capital inflows as well as the volume of capital outflows.

The debate over capital restrictions is almost ironic in the context of African countries. Because capital inflows are still low, one may argue that African countries need to attract capital inflows, not to control them. However, there are good reasons for an activist approach to capital account management in African countries. The conditions for full liberalization of capital movements are very hard to meet and they are largely lacking in most African countries. These conditions include low barriers to international trade, a well developed, a well diversified and well regulated financial system, and no large differences between the country's and world's tax regime on capital (Cooper 1999: 124). The following is the list of some of the reasons why African countries should selectively impose some restrictions on capital flows. 
Argument \#1: Protecting domestic financial systems.

A surge in international capital inflows can destabilize domestic financial systems. This is particularly the case for short-term capital flows, which have a high propensity for quick and sudden reversal. Given that financial systems are still underdeveloped in most African countries and that the regulatory framework is still weak, it may be necessary to adopt a selectively activist approach to capital account management. For example, South Africa suffered from contagion effects from the Asian financial crisis in 1997-98. The contagion effects worsened investor sentiments, causing large capital outflows and a depreciation of the rand.

\section{Argument \#2: Shaping industrial growth}

The evidence shows that private capital inflows to African countries still primarily target extractive activities, which contributes to perpetuating the dependence on the primary sector. Because extractive activities are predominantly capital intensive, capital inflows in those areas have little contribution to employment creation. It is desirable to design policies that can redirect foreign capital into new growth-promoting activities. Such policies include imposing a minimum stay requirement on foreign capital, establishing differential reserve requirements by type of capital in favor of growth-promoting capital, and providing preferential tax treatments to foreign capital that is directed to new employment-creating and growth-promoting activities.

\section{Argument \#3: Redistributive capital restrictions}

In Africa as in other developed and developing countries, the participation in capital markets is heavily skewed in favor of the wealthiest segments of the population. The majority of citizens are bystanders who derive little benefits from financial market 
booms while they often bear disproportionately high costs of financial fragility. African countries can devise policies aimed at redistributing the gains from capital markets expansion, which can contribute to improving the living standards of the population. For example, taxation of capital gains with the aim of increasing funding for socially productive public investment (health, education, nutrition, etc.) can have significant progressive effects.

Argument \#4: Protecting export performance

Unregulated capital flows can result in sharp fluctuations of exchange rates that can damage export performance. If high capital inflows result in the appreciation of the national currency, this will discourage international demand for national exports while encouraging imports of foreign goods, which depresses the current account balance. For emerging market African countries as well as others that have experienced a substantial increase in capital inflows, national authorities must consider options for activist management of capital flows to minimize potential adverse effects of capital flows on trade.

\section{Exchange regimes: transitions and implications for capital mobility \\ a. The global context: regime shifts and the "hollowing-out" of the middle}

Recent studies have observed marked shifts in exchange rate regimes around the world. These shifts are characterized by a "hollowing out" of the middle of the exchange rate regime spectrum where countries are moving from intermediate regimes ("soft pegs") to very hard pegs and independently floating regimes (Fischer 2001; Mussa et al. 
2000; Calvo and Reinhart 2000). ${ }^{3}$ These developments have been interpreted as the natural outcome of the increasing global integration of finance and trade. The recent crises that have hit emerging market economies in recent years have motivated research on the connections between the chances and severity of capital account crises and the exchange rate regimes. Some scholars have concluded that with few exceptions, these crises have had the most severe effects in emerging market countries that had either explicitly fixed exchange rate pegs or where movements in exchange rates were artificially constrained. In contrast, as the argument goes, emerging market countries that allowed flexibility of exchange rates fared better during crises (Mussa et al. 2000: 21).

It is still not clear whether the recent experience of emerging market crises constitutes evidence for a causal relationship between financial crises and exchange rate regimes. The nature of the exchange rate regime is nonetheless relevant because it can determine the ability of a country to hedge against a crisis and the magnitude of the crisis may depend on the particular exchange regime in place. In practice, however, sorting out the effects attributable to the exchange rate regime is difficult, partly because in many cases, financial market disturbances only amplify the effects of shocks that originate from the real side or from fundamental domestic policy misalignments. Recent experience shows that fiscal crises (like in Russia and Brazil), the weakness of the domestic financial system and excessive foreign currency-denominated borrowing in the corporate sector (like in Korea), the loss in competitiveness of the export sector, and other changes in the fundamental aspects of the economy have been central causes of financial crises. It is

\footnotetext{
${ }^{3}$ The hard pegs category includes regimes with a currency board or arrangements with no special legal tender; the soft pegs category includes other conventional fixed pegs, pegged rates in horizontal bands, crawling pegs, and pegged rates with crawling bands; the independent floats category includes independently floating and managed float with no pre-announced exchange rate path (Fischer 2001).
} 
nevertheless the case that for countries that are significantly integrated in the global financial markets, the choice of the exchange rate regime matters. In particular, such countries may find it costly to maintain rigidly fixed exchange rates.

\section{b. Exchange rate regime shifts in Africa: Asymmetric transition}

Many African countries have liberalized their foreign exchange markets and moved away from soft pegs towards independently floating or managed floating exchange rate regimes (see Table A1 in the appendix). However, these transitions have been asymmetric. While countries have moved out of the middle of the exchange regime spectrum, there has been virtually no movement out of or into the category of hard-peg regimes (Table A1 and Figure 5). Out of 51 African countries, 53\% were classified as having soft peg regimes in 1991. In 1999, only 24 percent of the countries are in this category.

Exchange rate regime transitions in Africa have mostly consisted of a movement of countries out of the soft pegs category (especially "conventional fixed pegs") into independent floats. Only Guinea-Bissau moved from the soft peg category to the hard peg category. The transition matrix in Table 4 indicates that over 55 percent of the countries (15 out of 27 countries) that were in the soft peg category in 1991 had adopted an independent floating regime by 1999 . In contrast, no shifts - with a single exception of Namibia which shifted from a hard peg to a soft peg - occurred among countries in both extremes of the exchange regime spectrum. The countries in the hard pegs category in 1999 are older members of the CFA zone - again except for Namibia - and GuineaBissau which joined the CFA zone in 1997. Similarly, all nine countries in the 
independent float category in 1991 were still in the same category in 1999. The existing evidence on African countries is inconclusive as to the relative advantages and disadvantages of alternative exchange rate regimes. I discuss some of the findings below.

\section{c. Exchange rate regimes and economic performance: casual observations}

It is difficult to establish a definitive relationship between economic performance and exchange rate regimes in Africa for many reasons. First, the classification of countries along the spectrum of exchange rate regimes from very hard pegs to independently floating regimes is arbitrary. Second, while the level and fluctuations in exchange rates can affect economic performance, it is only one of the many interrelated factors that determine a country's economic outcomes. Therefore, sorting out the effects that are attributable to shifts in exchange rate regimes is difficult. Sophisticated econometric analysis can help to address this issue, but such an exercise is not attempted in this study; for this reason, the following observations are rather casual and should not be interpreted as definitive empirical regularities.

Tables 5 and 6 present some indicators of economic performance for African countries classified by exchange rate regime. The results show that performance indicators vary widely within exchange rate regime categories. The information is summarized in Table 7, which presents the percentage of countries in each category whose economic indicators improved in the 1990s compared to the 1980s.

For the majority of countries in the hard pegs category (CFA zone members), there was little improvement in the growth of per capita GDP from the 1980s to the 1990s. While $50 \%$ of the countries in this group had a positive growth rate in the $1990 \mathrm{~s}$, 
the growth rate was higher than in the 1980 s for only $36 \%$ of the countries in this category. Inflation was higher and trade was lower in the 1990s compared to the 1980 s for $71 \%$ of the countries in this group.

However, two important empirical facts are worth emphasizing for the CFA zone. First, countries in this group experienced much lower inflation rates than countries in the other groups both in the 1980s and the 1990s. Virtually all the countries in the hard peg group had single-digit inflation rates (except for Guinea-Bissau, which joined the CFA zone in 1997). Second, as the data in Table 8 show, countries in the CFA zone experienced some improvement in economic performance following the devaluation of the CFA in $1994 .{ }^{4}$ The growth rate of GDP per capita was higher in 1995-98 than in 1990-94. The average growth rate for the group was $2.3 \%$ per annum in $1995-98$ compared to $-2.8 \%$ in $1990-94$. Exports also were higher in $1995-98$ for all the countries in the group, the export-to-GDP ratio averaging $36 \%$ in $1995-98$ compared to $28 \%$ in 1990-94. No similar patterns are observed in other regional groupings on the continent (see Table 9 for the case of the SADC). ${ }^{5}$

In the soft pegs category, a larger proportion of countries $(82 \%)$ achieved positive GDP growth, although growth was positive and higher in the 1990s than in the 1980s for only 36 percent of the countries in this group. This group also experienced improvement in inflation (lower in 82 percent of the countries) and the current account balance

\footnotetext{
${ }^{4}$ See the text in the appendix for a brief history of the CFA zone and its operational structure. Also see Honohan and Lane (2000) and Guillaumont, Guillaumont, and Plane (1988) for quantitative analyses of economic performance in the CFA zone. The finding of low inflation in countries with fixed peg regimes is consistent with the results from existing cross-country studies (see Ghosh et al. 1997).

5 The choice of the year 1994 to split the 1990s decade for the SADC group is primarily for comparison purposes with CFA zone countries. For South Africa, 1994 is historically important as it marks the end of the apartheid era, so this year is a natural break point for this country.
} 
(improved in 60 percent of the countries), and international reserves (higher stock of reserves in 80 percent of the countries).

The proportion of countries with improvement in GDP growth is lowest in the independent floats category. Inflation is higher in more than half of the countries in this group (54\%). However, the majority of the countries in this group show greater performance in trade $(73 \%)$ and international reserves $(85 \%)$.

In examining the links between exchange rate regimes and economic performance, the group of countries that shifted from one regime to another may provide better information than those countries whose regimes remained unchanged over the investigation period. Looking at the group of countries that shifted from soft pegs to independent floats, the shift was not associated with much gain in terms of output growth while inflation and current account records are worse than in the three categories of "nonshifters.' However, this category has the highest proportion of countries with improved performance in trade and international reserves.

Overall, these casual observations reveal no systematic relationship between indicators of economic performance and patterns of exchange rate regime shifts. The transition toward floating regimes was not accompanied by much gain in GDP growth, while inflation and current account performance worsened for the majority of regime shifters. In the case of CFA-zone countries, the re-alignment of the CFA exchange rate in 1994 was followed by significant improvements in output growth and trade. Due to ill-advised delayed adjustment in the exchange rate of the CFA franc, price stability was achieved at the cost of lower output growth and lower trade performance. Much more 
empirical work is needed to establish empirical regularities about the relationship between economic performance and exchange rate regimes in African countries.

\section{d. Further issues related to exchange regimes}

The exchange rate as a nominal anchor

As African countries move to liberalizing their exchange rate regimes, they confront some important policy questions. In particular, under a flexible exchange rate, the exchange rate no longer plays the role of a nominal anchor of monetary policy. National authorities must then determine a credible alternative nominal anchor. One alternative is to target inflation. This option appears to have worked fairly well in industrialized countries. However, important institutional conditions are necessary for this alternative to work. In particular, successful inflation targeting requires a high degree of instrument independence of the central bank. ${ }^{6}$ Monetary policy must be free from fiscal policy pressures and political intrusion. Moreover, inflation targeting requires a sound information base in forecasting inflation and output. These conditions are generally not met in a typical African country. Furthermore, inflation targeting is difficult when the economy is hit frequently by supply shocks. The majority of African economies experience frequent supply shocks, which include both domestic shocks (natural disasters, such as drought) and international shocks (like energy crisis and commodity price shocks). These effects can be hard to disentangle, which makes it

\footnotetext{
${ }^{6}$ Instrument independence of the central bank refers to the freedom to choose the monetary policy instruments needed to meet given macroeconomic objectives. Goal independence means the central bank's freedom to set the ultimate goals of monetary policy. In practice, independence of the central bank is generally limited to instrument independence.
} 
difficult to determine whether inflation is the outcome of policy mistakes or the result of purely exogenous shocks or a combination of these factors.

No exchange regime is good for all, all the time

When the economy is predominantly subject to real/supply shocks, a rigidly fixed exchange regime can be destabilizing as it prevents the normal adjustment of the current and capital accounts to the shocks. A number of scholars support the following prescription: "if shocks are mostly real, float; otherwise fix" (Calvo and Reinhart 1999; Berg and Borenzstein 2000). In some ways, the experience of the CFA zone lends some support to this view. Failure to adjust the exchange rate as the economies in the zone were hit by exogenous real shocks (terms of trade shocks, energy crisis, etc.) proved to be costly for these economies. However, as Calvo and Reinhart (1999) indicate, in some recent crises, shocks have come through the capital account, thus containing real as well as nominal components. African countries that opt for fixed exchange rate regimes should preserve enough flexibility to respond to shocks in a timely manner by adjusting the official exchange rate.

Many scholars have argued that along the spectrum of exchange rate regimes, running from very hard pegs to freely floating regimes, those in the intermediate range (or soft pegs) are not viable beyond the short term (Obstfed and Rogoff 1995; Mussa et al. 2000; Fischer 2001). For countries that are significantly integrated in the world financial markets, so the argument goes, the only viable option is a flexible (possibly managed) exchange rate regime. However, for African countries that are not integrated in the international financial markets, a hard peg seems to be a very sensible option. The recent transition of African countries towards floating exchange rate regimes is puzzling. 
Except probably for the emerging market countries (Egypt, Morocco, Nigeria, and South Africa), African countries do not seem to have the institutional and infrastructure conditions required to benefit from fully flexible exchange regimes.

\section{Currency regimes, dollarization/euroization, and implications for capital flows a. Dollarization/euroization: the new context}

The increasing interest in the topic of currency regimes and dollarization (and euroization more recently) is, to a large extent, motivated by the changing international environment, which has cast doubt on the adequacy of many of the traditional policy prescriptions with regard to the management of international trade, foreign exchange markets, and international capital flows. Here, I emphasize three of the important new developments that have changed the international context of policy making in the domain of currency regimes.

The first change in the global environment is the fact that inflation crises around the world have abated significantly since the early 1990s. The argument for activist exchange rate management has traditionally involved the need to use the exchange rate as a means towards inflation stabilization. With the decline and stabilization of inflation in many countries, the argument for using exchange rate management as a stabilization tool has lost momentum. However inflation is still an important problem for many African countries. In light of this, there is good reason for exchange rate management to remain a core component of the agenda of economic stabilization.

The second factor is the recent surge in cross-border capital mobility around the

world. This development has rejuvenated the debate over the choice of the exchange rate 
regime. Two views have emerged on this subject. The first view (the bipolar view) is that only very hard pegs and independently flexible exchange rate regimes are viable in the financially integrating world (see Fischer 2001). The second view suggests that countries should simply abandon national currencies and adopt a strong and stable international currency, especially since in today's global capital markets, it is unwise to peg the exchange rate because it is too costly to defend. Obstfeld and Rogoff (1995: 74) suggest that "for most countries, it is folly to try to recapture the lost innocence of fixed exchange rates." Calvo and Reinhart (1999: 13) echo the proposition by arguing that "the limited effectiveness of capital controls provides the basis for reassessing the relative merits of fixed and flexible exchange rate policies. Dollarization may offer emerging market economies a viable and more market-friendly alternative to capital controls." We briefly discuss the advantages and disadvantages of dollarization further below.

The third factor is the creation of the European Monetary Union (EMU) and the adoption of the euro. The question is whether the creation of the EMU will spark more interest for the strengthening of monetary unions in Africa, the creation of new ones, and even the establishment of a continent-wide African monetary union (AMU).

\section{b. Advantages and disadvantages of dollarization/euroization}

\section{Advantages of dollarization}

Proponents of dollarization have advanced a number of advantages that countries may derive from adopting a strong foreign currency. Here we elaborate on four of these advantages (see Berg and Borensztein 2000 for more details). ${ }^{7}$ The first benefit from

\footnotetext{
${ }^{7}$ Note that the arguments in favor of or against dollarization discussed here apply for the case of euroization.
} 
dollarization is that it shields the national economy from the adverse effects of sharp fluctuations in exchange rates. The second advantage of dollarization is to raise international investors' confidence in the economy by lowering the risks arising from currency fluctuations, which stimulates capital inflows. Dollarization also reduces the spread between domestic and international interest rates by lowering domestic interest rates, which stimulates private domestic investment.

However, critiques of dollarization point out that while dollarization eliminates currency devaluation risk, it does not eliminate country-specific or sovereign risk. In fact, it may even increase sovereign risk in countries that are not fully dollarized (Berg and Borensztein 2000). In the case of African countries, sovereign risk is likely to remain high due to weak economic fundamentals, loose macroeconomic policies, and a turbulent political environment. Dollarization or euroization cannot be an insurance against fundamental political uncertainty or the adverse effects of bad macroeconomic policies.

The third alleged advantage of dollarization is to facilitate integration into the world economy. Integration would be facilitated especially by reducing uncertainty and transaction costs associated with the divergence in cross-country exchange rates.

Finally, proponents of dollarization argue that it can serve as an external agent of fiscal and monetary discipline and foster sound financial policies. The adoption of a foreign currency amounts to surrendering the option of monetary financing of government deficits as well as the possibility of using monetary policy for macroeconomic stabilization. However, evidence suggests that currency unions are not an antidote to fiscal indiscipline or political intrusion in the financial system. The 
experience of the CFA-zone countries in the 1980s is revealing on this point as discussed further below.

\section{Disadvantages of dollarization}

There are many disadvantages of dollarization, of which four are emphasized here. The first disadvantage of dollarization is the loss of a national currency. This is likely to meet political resistance because a national currency is a symbol of national sovereignty.

Second, dollarization implies a loss of seignorage revenue, that is, the resources created from printing interest-free cash in exchange for government securities. The adoption of dollarization or euroization implies that all the seignorage revenue accrues to the USA or the EMU members, which amounts to free credit by the dollarizing countries to the USA or the EMU countries with the exception of the provision of these currencies through official development aid. In principle it is possible to design a scheme through which the USA or the EMU can share the seignorage revenues with members of the currency zone, but as of today, there are no clear guidelines for the design of such a scheme.

The third disadvantage of dollarization is its high degree of irreversibility, or the lack of an 'exit option'. Unlike other currency arrangements (such as a currency board) where countries can elect to exit whenever they see fit, the costs of exiting from dollarization are rather prohibitive (Berg and Borensztein 2000). The reintroduction of a national currency is possible, but it is likely to absorb substantial administrative and logistical resources. Most importantly, it is likely that the new currency will be perceived 
as weaker than the dollar (or the euro), which, among other things, will adversely affect investor sentiments and probably depress capital inflows while fueling capital outflows.

The fourth disadvantage of dollarization is that the country relinquishes a large part of its macroeconomic policy autonomy by losing three important policy tools:

devaluation as a tool of current account and capital account management, the lender-oflast-resort function of the central bank, and monetary policy as a tool of macroeconomic stabilization. With respect to the lender-of-last-resort function, the inability of national authorities to intervene to protect the financial sector against adverse internal and external shocks is a high price to pay for dollarization. It is possible to argue that the increased presence of highly capitalized foreign banks that is likely to accompany dollarization can serve as an alternative potential rescue mechanism in the event of a liquidity crisis in the domestic banking sector. Another alternative rescue mechanism would be direct intervention of the central bank of the guarantor country (the USA or EMU countries). However, this leaves open the question of whether the penetration of foreign banks is necessarily desirable and whether the USA or EMU countries have the incentives to intervene to rescue troubled financial institutions in the dollarizing/euroizing country.

\section{c. Currency unions in Africa: opportunities and constraints}

In this subsection, I explore three questions related to currency regimes in Africa.

First, are currency areas or monetary integration the means towards greater trade integration? One of the potential advantages of currency unions is to foster trade among members of the zone. However, the evidence from African countries shows that currency unions and regional integration in general have not promoted trade. For example, intra- 
zone trade in the CFA zone represented about seven percent of total external trade of CFA countries for the 1994-2000 period, down from about 8.9\% between 1970 and 1993 (Hadjimichael and Galy 1997: 30) ${ }^{8}$ Low intra-regional trade in sub-Saharan Africa is due to a range of structural constraints, including lack of complementarity in production across countries and weak infrastructural linkages. Therefore, the adoption of a common currency in Africa will not necessarily increase intra-regional trade.

Second, are currency unions a means towards fiscal discipline, efficiency, and stability of the financial system? In principle, transferring financial and monetary policy to a supra-national institution can foster financial stability by reducing political pressure on credit allocation. However, the evidence from the CFA zone is not compelling in this regard either. The operating structure of the CFA zone, which delegates monetary and financial policies to the two regional central banks, did not insulate the economies from fiscal indiscipline and intrusive manipulation of credit allocation by member governments, especially through lending to state-owned enterprises, regional organizations, and government suppliers (Honohan and Lane 2000). These loans were characterized by very high default rates. As a result, the banking system was in severe crisis by the mid-1980s. African countries cannot count on successfully "outsourcing" fiscal and monetary policy by simply delegating it to regional monetary organizations. Nor can they expect dollarization or euroization to be a substitute for fiscal and financial reform.

Third, can currency unions foster international capital inflows? The creation of a currency union is expected to be accompanied by an expansion of markets and possibly a

\footnotetext{
${ }^{8}$ The average for 1994-2000 is computed using data from Direction of Trade Statistics Yearbook 2001. See Yeats (1999), Aryeetey et al. (1996) and Asante (1997) for in-depth discussions of trade and regionalism in Africa.
} 
reduction of country risk, which would increase international capital inflows. One potential negative effect is that with the expansion of the markets, African economies may no longer be "below the radar screen of international speculators" (Honohan and Lane 2000). This implies a need for efficient management of capital flows to reduce the risk of financial fragility.

\section{Capital flight: magnitude, causes, and macroeconomic implications a. Magnitude of the capital flight problem in African countries}

The problem of capital flight from African countries has attracted much attention for a while in the academic literature (for a survey, see Boyce and Ndikumana 2001; Ndikumana and Boyce 2002; Ajayi and Khan 2000). Existing studies show that African countries have experienced massive capital flight over time. This paper presents estimates of capital flight for a sample of 30 African countries for the period from 1970 to 1996 . These estimates are obtained using the methodology developed by Boyce and Ndikumana (2001) who compute capital flight as follows:

$$
K F_{i t}=\triangle D E B T A D J_{i t}+D F I_{i t}-\left(C A_{i t}+\Delta R E S_{i t}\right)+M I S I N V_{i t},
$$

where $\triangle D E B T A D J$ is the change in debt adjusted for cross-currency exchange rate fluctuations, taking into account the fact that a country's debt is denominated in various currencies; DFI is direct foreign investment, $C A$ is the current account balance, $\triangle R E S$ is the change in the stock of international reserves, and MISINV is net trade misinvoicing. Two modifications are made to the value obtained with the above equation. First nominal values of capital flight are deflated to real values using the US producer price 
index (base $1996=100$ ). Second, the accumulated stock of capital flight is computed by imputing interest earnings to past capital flight using the US Treasury Bill rate.

Table 10 presents capital flight estimates for 30 sub-Saharan African countries. The table contains estimates of total real capital flight from 1970 to 1996 in constant 1996 US dollars (column II), the stock of accumulated capital flight including interest earnings on past capital flight (columns III-V), and calculated net external assets (column VI) obtained by subtracting the stock of external debt in 1996 from the stock of accumulated capital flight with imputed interest earnings.

The results indicate that for the 30 African countries, real capital flight over the 26-year period amounted to about $\$ 182$ billion. Including interest earnings, the accumulated stock of capital flight is $\$ 272$ billion for the period. Total capital flight is higher if we consider only severely indebted low-income countries (SILIC). For this group, the estimates are $\$ 189.7$ billion and $\$ 281$ billion for total real capital flight and the accumulated stock of capital flight, respectively. The sample as a whole is a "net creditor to the world" in the sense that private assets held abroad as measured by capital flight exceed total liabilities as measured by the stock of debt. Estimated net external assets amount to $\$ 81.7$ billion for the entire sample of 30 African countries and $\$ 102.7$ billion for the SILIC group.

The magnitude of capital flight varies significantly across African countries. Angola, Cameroon, Côte d'Ivoire, the Democratic Republic of Congo, and Nigeria have particularly high levels of capital flight, with as much as $\$ 86.8$ billion for Nigeria. The capital-flight/GDP ratio exceeds $200 \%$ for 9 countries in the sample. The data also 
indicates a high per capita burden of capital flight amounting to several multiples of per capita income (comparing columns I and V in Table 10).

\section{b. Conduits, causes, and macroeconomic consequences of capital flight}

There are various conduits through which private actors can channel capital flight abroad illegally. Capital flight occurs through illicit bank transfers, embezzlement of exports of minerals and other natural resources, and misinvoicing of exports and imports. The amounts are notoriously high for some countries, including Nigeria with $\$ 23.6$ billion, the DRC with $\$ 7.4$ billion, and Côte d'Ivoire with $\$ 6.7$ billion (Boyce and Ndikumana 2001).

Some studies have investigated the causes or determinants of capital flight using both cross-country data and country case studies. Ndikumana and Boyce (2002) examine the determinants of capital flight from 30 sub-Saharan Africa. They find that external borrowing is positively and significantly related to capital flight, suggesting that to a large extent capital flight is debt-fueled. Their results also indicate that capital flight exhibits a high degree of persistence in the sense that past capital flight is correlated with current and future capital flight. The growth rate of per capita GDP and an index of voice and accountability are negatively related to capital flight. The findings in Ndikumana and Boyce (2001) are consistent with the results from studies on smaller samples as well as country case studies. These include Lensink, Hermes, and Murinde (2000) who find that capital flight is higher in countries with high corruption, bad governance, and high political instability. Olopoenia (2000) finds that capital flight from Uganda was higher during the periods of political and economic instability in the 1970s and the first half of 
the 1980s. Nyoni (2000) finds that the black market premium, which is an indicator of market distortions, significantly and positively influences the level of capital flight. Lensink, Hermes, and Murinde (1998) find that capital flight declines following financial liberalization, indicating that reducing market distortions can contribute to reducing capital flight.

Compared to other developing regions, sub-Saharan Africa has experienced a relatively higher level of capital flight. Collier, Hoeffler, and Pattillo (1999) find that Africa has the highest proportion of private capital held abroad (as a percentage of total private assets or GDP). Using a portfolio choice approach, these authors find econometric results suggesting that high capital flight from Africa was due, among other things, to overvalued exchange rates, high country-specific risk, and high indebtedness.

Capital flight implies a high opportunity cost for the economy and a heavy burden on the population. High capital flight implies that scarce resources are used to channel private assets abroad instead of financing imports of investment equipment or consumption goods. Capital flight also puts pressure on the exchange rate by increasing the demand for foreign currency to funnel wealth abroad. Past and current capital flight constitutes a drain on national resource, and thus reduces the current and future growth potential of the country. Capital flight contributes to increasing macroeconomic uncertainty, which depresses lending and investment. Market participants may interpret high capital flight as a signal of loss of control of economic policy by national authorities. Through herd effects, capital flight can lead to more capital flight as agents seek to minimize expected portfolio losses in the face of an uncertain future political and economic environment. 


\section{c. Capital account liberalization and capital flight}

The net effects of capital account liberalization on capital flight are unpredictable. Capital account liberalization can lead to a decline in capital flight due to the removal of market distortions. However, capital account liberalization can curtail capital flight only if it is part of a broader reform agenda aimed at fostering an environment that is conducive to investment.

\section{Capital account liberalization when financial markets are repressed}

Three issues are worth emphasizing with regard to capital account liberalization. First, capital account liberalization has adverse effects when financial markets are repressed. If domestic interest rates are significantly lower than foreign interest rates due to financial repression, then profit-maximizing savers prefer to hold their wealth in foreign assets. Substantially repressed interest rates can lead to disintermediation as savings are channeled abroad while banks refuse to lend at negative real interest rates. The implication of this highly stylized argument is that African countries must coordinate their capital account liberalization programs with financial reforms to eliminate interest rate repression. There is some evidence that financial liberalization can in fact play an important role in curtailing capital flight (Lensink, Hermes, and Murinde 1998).

Second, the liberalization of capital account operations in the context of overvalued exchange rates can cause higher capital flight and can have detrimental effects on the current account. An overvalued exchange rate induces agents to underinvoice exports while overinvoicing imports, which increases capital flight. African countries need to coordinate capital account liberalization with exchange regime liberalization to avoid costly market distortions. 
Third, political instability causes capital flight as agents seek to minimize the risk of expropriation and future portfolio losses due to political crisis. Current account liberalization or any other economic reform would have little effect in reducing capital flight in the presence of high political uncertainty. Therefore economic liberalization must go hand in hand with institutional reforms aimed at fostering transparent and accountable governance.

\section{Summary and policy implications}

\subsection{Attracting and monitoring capital flows}

African countries need to design strategies to attract foreign private capital to compensate for the recent decline in official lending. The evidence suggests that private capital flows are responsive to the macroeconomic policy environment. The focus should be on reform policies aimed at improving fiscal discipline, controlling inflation, and creating an investment friendly environment. Indeed countries that have made progress in economic reform have also experienced an increase in capital inflows (e.g., Mozambique, Tanzania, and Uganda).

Gauging the effects of capital flows on macroeconomic performance and designing appropriate policy responses requires good information on the nature, the magnitude, the sectoral distribution, and the variability of capital flows. Unfortunately such information is still scarce in African countries. African governments need to invest financial and human resources to establish mechanisms for systematic monitoring of the inflows and outflows of capital. This could include the creation or strengthening of 
specialized divisions within central banks and national bureaus of statistics whose mission would be to compile and disseminate information on capital movements.

\subsection{On liberalization and openness: a cautionary note}

Two points are worth emphasizing with regard to the recent moves towards greater flexibility of exchange rates and openness of capital account regimes in African countries. First, liberalization of current and capital accounts will enhance economic performance only if it is supported by appropriate macroeconomic and sectoral policies, especially disciplined fiscal policy and monetary policy committed to price stability.

Second, to avoid potential adverse effects of capital account liberalization, African countries need to undertake the necessary steps to reduce market distortions.

\subsection{Strengthening financial markets}

Underdeveloped financial markets constitute an important constraint to private capital inflows in Africa, especially because of the lack of opportunities for portfolio diversification. At the same time, with underdeveloped financial markets and a weak regulatory infrastructure, African countries are ill equipped to absorb large and sudden surges in capital inflows. Among other things, African countries need to pursue reforms aimed enforcing creditor and investor rights and improving the efficiency of the clearing system. These measures will both facilitate financial development and encourage capital inflows.

The role of stock markets in attracting private capital to Africa is a topic that deserves careful investigation. The evidence shows that countries such as Kenya and Zimbabwe have failed to attract significant capital inflows despite the fact that they have long-established stock markets. While stock markets can contribute to attracting private 
capital, they are not a sufficient condition. African countries need to pursue policies aimed at facilitating financial intermediation in general, which will promote the banking sector as well as equity markets. A solid banking system is essential to the development of the stock market because stock market development and banking development are complementary (Levine and Zervos 1998).

Given the small size of African national stock markets (with the exception of South Africa), they are not yet in a position to attract sizeable foreign capital. The development of regional stock exchanges can contribute to alleviating this small-size constraint. The creation of national stock markets involves high costs (infrastructure and administrative costs) that small economies cannot afford in the short run. Operating rules (accounting rules, prudential regulation rules, etc.) need to be coordinated across countries to facilitate cross-border listings and increase the benefit of regional integration.

\section{References}

Ajayi I and M Khan, eds. (2000). External Debt and Capital Flight in Sub-Saharan Africa. Washington, DC: The IMF Institute.

Ariyoshi A, K Habermeier, B Laurens, I tker-Robe, J I Canales-Kriljenko, and A Kirilenko (2000). Capital controls: Country experiences with their use and liberalization. Occasional Paper 190, IMF.

Aryeetey E, P Robinson, W Lyakurwa, and P Mistry (1996). Regionalism and the Global Economy. The Case of Africa. The Hague, FONDAD.

Asante S.K.B. (1997). Regionalism and Africa's Development. Expectations, Reality, and Challenges. New York, St. Martin Press.

Azam, Jean-Paul (1999) "Dollars for Sale: Exchange Rate Policy and Inflation in Africa," World Development, 27 (10), 1843-1859.

Berg A and E Borensztein (2000). The pros and cons of full dollarization. Working paper 00/50, IMF.

Bhinda N, S Griffith-Jones, J Leape, and M Martin (1999). Private Capital Flows to Africa. Perceptions and Reality. The Hague, FONDAD.

Boyce J and L Ndikumana (2001). Is Africa a net creditor? New estimates of capital flight from severely indebted sub-Saharan African countries, 1970-1996. The Journal of Development Studies,38 (2), 27-56. 
Calvo G. and C Reinhart (2000). Fear of Floating. working paper 7993, NBER.

Calvo G. and C Reinhart (1999). Capital flow reversals, the exchange rate debate, and dollarization. Finance and Development (September), 13-15.

Collier P and J W Gunning (1999a) Explaining African economic performance. Journal of Economic Literature, 37(1): 64-111.

Collier P and J W Gunning (1999b) Why has Africa grown slowly? Journal of Economic Perspectives, 13(3): 3-22.

Collier P, A Hoeffler, and C Pattillo (1999). Flight capital as a portfolio choice. Unpublished manuscript, World Bank.

Collier P and C Pattillo (2000). Investment and risk in Africa. In Collier P and C Pattillo, eds. Investment and Risk in Africa, New York, St. Martin Press: 3-30.

Cooper R (1999). Should capital controls be banished? Brookings Papers on Economic Activity 1: 89-141.

Fajgenbaum J, R Sharer, K Thugge, and H DeZoysa (1999). The Cross-Border Initiative in Eastern and Southern Africa. IMF, July 14.

Fischer S (2001) Exchange rate regimes: Is the bipolar view correct? Journal of Economic Perspectives, 15 (2): 3-24.

Fischer S (1999). Capital account liberalization and the role of the IMF In Should the IMF Pursue Capital-Account Convertibility? Princeton: Princeton University, Essays in International Finance no. 207: 1-10.

Gelbard E and S P Leite (1999). Measuring financial development in sub-Saharan Africa. Working paper 99/105, IMF.

Ghosh A, A-M Guld, J Ostry, and H Wolf (1997). Does the nominal exchange rate regime matter? Working paper 5874, NBER.

Guillaumont P, S Guillaumont, and P Plane (1988). Participating in African monetary unions: An alternative evaluation. World Development 16(5): 569-576.

Hadjimichael M and M Galy (1997). The CFA franc zone and the EMU. Working paper 97/156, IMF.

Haque U N, N Mark, and D Mathieson (2000). Rating Africa: The economic and political content of risk indicators. In Collier P and C Pattillo, eds. Investment and Risk in Africa, New York: St. Martin Press, 33-70.

Honohan P and P Lane (2000). Will the euro trigger more monetary unions in Africa? Working paper 2393, World Bank.

IMF (2000). Annual Report on Exchange Arrangements and Exchange Restrictions, Washington, DC, The IMF.

IMF (2001). Malawi: Selected issues and statistical appendix. Country Report No. 01/32, IMF.

IMF (2000). South Africa: Selected Issues. Staff Country Report No. 00/42, IMF.

IMF (1998). Nigeria: Selected issues and statistical appendix. Staff Country Report No. 98/78, IMF.

Kasekende L, D Kitabire, and M Martin (1999). Capital flows and macroeconomic policy in sub-Saharan Africa. In G.K. Helleiner, ed. Capital account regimes and the developing countries. New York, St. Martin Press: 141-183.

Krichene N (1998). Purchasing power parities in five East African countries: Burundi, Kenya, Rwanda, Tanzania, and Uganda. Working paper 98/148, IMF. 
Lensink R, N Hermes, and V Murinde (2000). Capital flight and political risk. Journal of International Money and Finance, 19: 73-92.

Lensink R, N Hermes, and V Murinde (1998). The effect of financial liberalization on capital flight in African economies, World Development 26(7): 1349-1368.

Levine R and S Zervos (1998). Stock markets, banks, and economic growth. American Economic Review, 88 (3): 537-557.

Mecagni M and M Sourial (1999). The Egyptian stock market: Efficiency tests and volatility effects. Working paper 99/48, IMF.

Mehran H, P Ugolini, J P Briffaux, G Iden, T Lybek, S Swaray, and P Hayward (1998). Financial sector development in sub-Saharan African Countries. Occasional Paper 169 , IMF.

Mongardini J (1998). Estimating Egypt's equilibrium real exchange rate. Working paper 98/5, IMF.

Mussa M, P Masson, A Swoboda, E Jadresic, P Mauro, and A Berg (2000). Exchange rate regimes in an increasingly integrated world economy. Occasional paper No. 193, IMF.

Ndikumana L (2001). Financial markets and economic development in Africa, Working paper 17, Political Economy Research Institute, University of Massachusetts.

Ndikumana L and JK Boyce (2002). Public Debts and Private Assets: Explaining Capital Flight from Sub-Saharan African Countries. Department of Economics, University of Massachusetts, working paper 2002-2, forthcoming in World Development, 31(1), January 2003..

Ndikumana L and J K Boyce (1998). Congo's odious debt: External borrowing and capital flight in Zaïre. Development and Change, 29: 1995-217.

Nissanke M and E Aryeetey (1998). Financial Integration and Development in SubSaharan Africa. London, Routledge.

Nyoni T (2000). Capital flight from Tanzania. In Ajayi I and M Khan, eds. External Debt and Capital Flight in Sub-Saharan Africa. Washington, D.C., The IMF Institute: 265-299.

Obstfeld M and K Rogoff (1995). The mirage of fixed exchange rates. Journal of Economic Perspectives, 9(4): 73-96.

Olopoenia R (2000). Capital flight from Uganda, 1971-94. In Ajayi I and M Khan, eds. External Debt and Capital Flight in Sub-Saharan Africa. Washington, D.C., The IMF Institute: 238-264.

Savvides, Andreas (1996) "CFA Franc Zone Membership and Exchange Rate Variability," Journal of African Economies, 5 (1), 52-68.

Singh A (1999). Should Africa promote stock market capitalism? Journal of International Development, 11: 343-365.

Singh, A and B Weisse (1998). Emerging stock markets, portfolio capital flows and long-term economic growth: Micro and macroeconomic perspectives. World Development, 26(4): 607-622.

Subramanian A and H Handy (1997). The Egyptian stabilization experience: An analytical retrospective. Working paper 97/105, IMF.

UNCTAD World Investment Report (various issues from 1992 to 2000). New York and Geneva, The United Nations. 
UNCTAD (1995). Foreign Direct Investment in Africa. New York and Geneva, The United Nations.

World Bank (1997). Private Capital Flows to Developing Countries. The Road to Financial Integration. New York, Oxford University Press for the World Bank.

World Bank, Global Development Finance (2000 and 1997 CDROM editions).

Washington, D.C., The World Bank.

World Bank (2000). World Development Indicators 2000. Washington, D.C., The World Bank.

Yeats A (1999). What can be expected from African regional trade arrangements? Working paper 2004, The World Bank. 
Table 1: FDI inflows: volume (million \$) and \% of gross domestic investment, 1981-1998

\begin{tabular}{|c|c|c|c|c|c|c|}
\hline \multirow[t]{2}{*}{ Country } & \multicolumn{3}{|c|}{ FDI inflows (annual average) } & \multicolumn{3}{|c|}{ FDI as $\%$ of gross domestic investment } \\
\hline & $1981-85$ & $1986-91$ & $1992-98$ & $1981-85$ & $1986-91$ & $1992-98$ \\
\hline Algeria & -7.9 & 8 & 9 & 0.0 & 0.0 & 0.1 \\
\hline Angola & 278 & 169 & 420 & 22.5 & 14.4 & 33.3 \\
\hline Benin & 0.5 & 3 & 16 & 0.3 & 1.3 & 4.6 \\
\hline Botswana & 49.8 & 59 & 4 & 14.3 & 7.2 & 0.3 \\
\hline Burkina Faso & 1.3 & 2 & 12 & 0.5 & 0.4 & 2.2 \\
\hline Burundi & 0.5 & 1 & 1 & 0.3 & 0.6 & 0.9 \\
\hline Cameroon & 158.9 & -16 & 23 & 8.1 & -0.7 & 1.6 \\
\hline Central African Republic & 5.5 & 2 & 0 & 6.9 & 1.3 & 0.2 \\
\hline Chad & NA & 12 & 15 & NA & 11.2 & 7.9 \\
\hline Congo, Dem. Rep. & -17.8 & -10 & 2 & -1.7 & -1.0 & 0.3 \\
\hline Congo, Rep. & 34 & 15 & 26 & 3.9 & 3.3 & 3.2 \\
\hline Côte d' Ivoire & 33.7 & 49 & 187 & 2.4 & 4.9 & 14.5 \\
\hline Egypt & 688.7 & 932 & 772 & 8.5 & 8.7 & 7.0 \\
\hline Ethiopia & NA & NA & 62 & NA & NA & 6.6 \\
\hline Gabon & 64.3 & 53 & 67 & 5.0 & 4.1 & 5.3 \\
\hline Ghana & 8.5 & 11 & 107 & 3.5 & 1.6 & 7.8 \\
\hline Guinea & 0.2 & 18 & 12 & NA & 4.3 & 1.7 \\
\hline Kenya & 15.9 & 35 & 20 & 1.3 & 2.2 & 1.4 \\
\hline Lesotho & 3.9 & 11 & 198 & 2.8 & 3.8 & 32.0 \\
\hline Liberia & 20.8 & 200 & 15 & 15.5 & 190.5 & NA \\
\hline Libya & -272.2 & 45 & -39 & -3.3 & NA & NA \\
\hline Madagascar & 2.2 & 12 & 13 & 0.7 & 3.7 & 3.3 \\
\hline Malawi & 7.6 & 15 & 26 & 3.4 & 5.3 & 8.7 \\
\hline Mali & 4.3 & NA & 38 & 2.2 & NA & 6.8 \\
\hline Mauritania & 8.9 & 3 & 6 & 4.2 & 1.3 & 3.0 \\
\hline Mauritius & 3.4 & 24 & 25 & 1.5 & 3.8 & 2.4 \\
\hline Morocco & 50.4 & 132 & 509 & 1.4 & 2.6 & 7.4 \\
\hline Mozambique & NA & 8 & 70 & NA & 2.4 & 13.7 \\
\hline Namibia & NA & 26 & 102 & NA & 6.8 & 16.2 \\
\hline Niger & 3.1 & 16 & 14 & 1.2 & 5.9 & 8.9 \\
\hline Nigeria & 400.3 & 728 & 1352 & 5.8 & 17.0 & 23.6 \\
\hline Rwanda & 15.9 & 14 & 3 & 6.7 & 4.3 & 1.4 \\
\hline Senegal & 8.2 & 13 & 54 & 2.7 & 2.1 & 6.8 \\
\hline Seychelles & 10.1 & 20 & 34 & 25.2 & 28.1 & 20.4 \\
\hline Sierra Leone & -2.2 & -10 & -1 & -5.6 & -12.3 & -1.1 \\
\hline South Africa & NA & -27 & 965 & NA & -0.2 & 4.5 \\
\hline Sudan & NA & -4 & 94 & NA & -0.1 & NA \\
\hline Swaziland & 6.9 & 53 & 22 & 4.4 & 37.0 & 6.7 \\
\hline Tanzania & 8.8 & NA & 102 & NA & NA & 8.9 \\
\hline Togo & 6.9 & 10 & 21 & 4.3 & 3.8 & 10.4 \\
\hline Tunisia & 207.6 & 83 & 474 & 7.6 & 2.9 & 10.0 \\
\hline Uganda & NA & NA & 111 & NA & NA & 14.2 \\
\hline Zambia & 19.2 & 100 & 108 & 3.7 & 24.3 & 22.6 \\
\hline Zimbabwe & 0.2 & 10 & 125 & 0.0 & 0.7 & 8.6 \\
\hline
\end{tabular}

Sources: UCTAD, World Investment Report (1998 and 2000); UNCTAD (1995), FDI in Africa. 
Table 2: International capital flows to sub-Saharan Africa: volume (million 1995 \$) and share in developing countries

\begin{tabular}{|c|c|c|c|c|c|c|c|c|c|c|c|c|}
\hline Indicator & & 1989 & 1990 & 1991 & 1992 & 1993 & 1994 & 1995 & 1996 & 1997 & 1998 & 1999 \\
\hline Long term debt* & $\begin{array}{l}\text { Volume } \\
\text { Share }(\%)\end{array}$ & $\begin{array}{r}7055 \\
17.3\end{array}$ & $\begin{array}{r}4306 \\
9.2\end{array}$ & $\begin{array}{r}3705 \\
7.8\end{array}$ & $\begin{array}{r}3709 \\
5.8\end{array}$ & $\begin{array}{r}5245 \\
6.8\end{array}$ & $\begin{array}{r}4520 \\
6.9\end{array}$ & $\begin{array}{r}3973 \\
4.8\end{array}$ & $\begin{array}{r}821 \\
0.8\end{array}$ & $\begin{array}{r}2246 \\
2.0\end{array}$ & $\begin{array}{r}-428 \\
\text { NA }\end{array}$ & $\begin{array}{r}1347 \\
3.0\end{array}$ \\
\hline $\begin{array}{l}\text { Grants excl. tech. } \\
\text { Coop. }\end{array}$ & $\begin{array}{l}\text { Volume } \\
\text { Share }(\%)\end{array}$ & $\begin{array}{r}10711 \\
49.8\end{array}$ & $\begin{array}{r}13048 \\
41.7\end{array}$ & $\begin{array}{r}11893 \\
29.7\end{array}$ & $\begin{array}{r}12091 \\
36.0\end{array}$ & $\begin{array}{r}10890 \\
36.6\end{array}$ & $\begin{array}{r}12396 \\
36.6\end{array}$ & $\begin{array}{r}11414 \\
34.9\end{array}$ & $\begin{array}{r}9989 \\
36.5\end{array}$ & $\begin{array}{r}9464 \\
37.3\end{array}$ & $\begin{array}{r}10274 \\
37.8\end{array}$ & $\begin{array}{r}10127 \\
38.3\end{array}$ \\
\hline FDI & $\begin{array}{l}\text { Volume } \\
\text { Share }(\%)\end{array}$ & $\begin{array}{r}5335 \\
16.8\end{array}$ & $\begin{array}{r}2361 \\
6.5\end{array}$ & $\begin{array}{r}2998 \\
6.9\end{array}$ & $\begin{array}{r}3377 \\
6.2\end{array}$ & $\begin{array}{r}3826 \\
5.0\end{array}$ & $\begin{array}{r}5835 \\
5.4\end{array}$ & $\begin{array}{r}4699 \\
4.2\end{array}$ & $\begin{array}{r}5399 \\
3.8\end{array}$ & $\begin{array}{r}6743 \\
3.9\end{array}$ & $\begin{array}{r}7540 \\
4.2\end{array}$ & $\begin{array}{r}8974 \\
4.3\end{array}$ \\
\hline $\begin{array}{l}\text { Portfolio equity } \\
\text { investment }\end{array}$ & $\begin{array}{l}\text { Volume } \\
\text { Share }(\%)\end{array}$ & $\begin{array}{r}0 \\
0.0\end{array}$ & $\begin{array}{r}0 \\
0.0\end{array}$ & $\begin{array}{r}0 \\
0.0\end{array}$ & $\begin{array}{r}153 \\
1.3\end{array}$ & $\begin{array}{r}183 \\
0.3\end{array}$ & $\begin{array}{r}891 \\
2.4\end{array}$ & $\begin{array}{r}4868 \\
13.5\end{array}$ & $\begin{array}{r}1967 \\
4.1\end{array}$ & $\begin{array}{r}1474 \\
5.0\end{array}$ & $\begin{array}{r}681 \\
4.4\end{array}$ & $\begin{array}{r}493 \\
1.8\end{array}$ \\
\hline $\begin{array}{l}\text { Net private resource } \\
\text { flows }\end{array}$ & $\begin{array}{l}\text { Volume } \\
\text { Share (\%) }\end{array}$ & $\begin{array}{l}\text { NA } \\
\text { NA }\end{array}$ & 1377 & $\begin{array}{l}\text { NA } \\
\text { NA }\end{array}$ & $\begin{array}{l}\text { NA } \\
\text { NA }\end{array}$ & 2887 & 5087 & 9501 & 5424 & 9396 & 3461 & 7264 \\
\hline
\end{tabular}

Sources: World Bank, Global Development Finance (1997, 2000); UNCTAD, World Investment Report (1998, 2000).

Nominal values are converted into real values using the US producer price index.

* Net flows of long-term debt, excluding IMF credit. 
Table 3: FDI inflows in selected African countries, 1986-1999 (million constant 1995 \$)

\begin{tabular}{l|rrrrrrrrrrrrrr}
\hline \multicolumn{1}{c}{ Country } & 1986 & 1987 & 1988 & 1989 & 1990 & 1991 & 1992 & 1993 & 1994 & 1995 & 1996 & 1997 & 1998 & 1999 \\
Oil exporting countries & & & & & & & & & & & & \\
\end{tabular}

Source: UNCTAD, World Investment Report (various editions 1992 to 2000). Nominal values are converted into real values using the US producer price index. 
Table 4. Exchange rate regime shifts in Africa from 1991 to 1999: Transition matrix

\begin{tabular}{|c|c|c|c|c|c|}
\hline \multirow{6}{*}{ 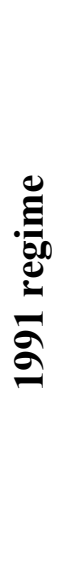 } & \multicolumn{5}{|c|}{1999 regime } \\
\hline & & Hard pegs & Soft pegs & $\begin{array}{l}\text { Independent } \\
\text { floats }\end{array}$ & Total \\
\hline & Hard pegs & $\begin{array}{r}14 \\
(93.3 \%) \\
\end{array}$ & $\begin{array}{r}1 \\
(6.7 \%) \\
\end{array}$ & $\begin{array}{r}0 \\
(0 \%) \\
\end{array}$ & $\begin{array}{r}15 \\
(29 \%)\end{array}$ \\
\hline & Soft pegs & $\begin{array}{r}1 \\
(3.7 \%) \\
\end{array}$ & $\begin{array}{r}11 \\
(40.7 \%) \\
\end{array}$ & $\begin{array}{r}15 \\
(55.6 \%) \\
\end{array}$ & $\begin{array}{r}27 \\
(53 \%) \\
\end{array}$ \\
\hline & Independent floats & $\begin{array}{r}0 \\
(0 \%)\end{array}$ & $\begin{array}{r}0 \\
(0 \%)\end{array}$ & $\begin{array}{r}9 \\
(100 \%)\end{array}$ & $\begin{array}{r}9 \\
(18 \%)\end{array}$ \\
\hline & Total & $\begin{array}{r}15 \\
(29 \%)\end{array}$ & $\begin{array}{r}12 \\
(24 \%)\end{array}$ & $\begin{array}{r}24 \\
(47 \%)\end{array}$ & $\begin{array}{r}51 \\
(100 \%)\end{array}$ \\
\hline
\end{tabular}

The cells contain the number of countries (and percentage of the sample) transitioning from a given regime in 1991 to a regime in 1999. The 'hard peg' category includes regimes with a currency board or arrangements with no special legal tender; the 'soft peg' category includes other conventional fixed pegs, pegged rates in horizontal bands, crawling pegs, and rates with crawling bands; the 'independent floats' category includes independently floating and managed float with no pre-announced exchange rate path. 
Table 5: GDP growth, current account, international reserves, and inflation in African countries by exchange rate regime, 1980-1998.

\begin{tabular}{|c|c|c|c|c|c|c|c|c|}
\hline \multirow[t]{2}{*}{ Country/regime 1999} & \multicolumn{2}{|c|}{$\begin{array}{l}\text { Growth of per capita GDP } \\
\text { (annual } \% \text { )* }\end{array}$} & \multicolumn{2}{|c|}{$\begin{array}{l}\text { Current account balance } \\
(\% \text { GDP })\end{array}$} & \multicolumn{2}{|c|}{$\begin{array}{l}\text { Net international reserves } \\
(\% \text { GDP })\end{array}$} & \multicolumn{2}{|c|}{$\begin{array}{c}\text { Inflation (average \% change, } \\
\text { GDP deflator) }\end{array}$} \\
\hline & $1980-89$ & $1990-98$ & $1980-89$ & $1990-98$ & $1980-89$ & $1990-98$ & $1980-89$ & $1990-98$ \\
\hline \multicolumn{9}{|l|}{ Group I. Hard pegs } \\
\hline Benin & -0.5 & 1.7 & -6.6 & -2.2 & 0.7 & 11.4 & 2.9 & 7.9 \\
\hline Burkina Faso & 1.4 & 1.1 & -2.1 & -4.6 & 8.9 & 14.3 & 4.6 & 4.8 \\
\hline Cameroon & 1.6 & -2.1 & -4.2 & -2.7 & 1.3 & 0.1 & 6.2 & 4.8 \\
\hline Central African Republic & -0.8 & -0.6 & -4.6 & -5.6 & 7.5 & 14.4 & 9.3 & 4.2 \\
\hline Chad & 3.9 & -0.9 & -0.6 & -4.8 & 3.2 & 7.0 & 2.7 & 7.5 \\
\hline Congo, Rep. & 0.9 & -1.9 & -13.1 & -24.5 & 1.5 & 1.4 & 4.4 & 4.4 \\
\hline Côte d'Ivoire & -2.9 & 0.6 & -9.7 & -5.4 & 0.1 & 3.1 & 3.5 & 6.2 \\
\hline Djibouti & NA & -5.3 & NA & -10.0 & 15.5 & 17.1 & NA & 4.1 \\
\hline Equatorial Guinea & -1.4 & 14.3 & -17.3 & -37.0 & 3.4 & 2.1 & -0.8 & 9.3 \\
\hline Gabon & -2.9 & 0.7 & -3.6 & 1.8 & 4.0 & 3.2 & 3.5 & 6.2 \\
\hline Guinea-Bissau & 1.7 & -1.2 & -41.0 & -21.1 & 6.2 & 6.7 & 57.7 & 41.3 \\
\hline Mali & -1.8 & 0.8 & -10.4 & -8.7 & 1.7 & 13.1 & 5.3 & 7.6 \\
\hline Niger & -3.6 & -1.3 & -7.7 & -8.3 & 7.1 & 6.7 & 3.3 & 4.8 \\
\hline Senegal & 0.3 & 0.2 & -11.4 & -5.4 & 0.3 & 4.0 & 6.7 & 4.4 \\
\hline Togo & -1.5 & -0.7 & -4.9 & -8.5 & 23.1 & 12.7 & 5.6 & 7.5 \\
\hline \multicolumn{9}{|l|}{ Group II. Soft pegs } \\
\hline Botswana & 6.4 & 1.7 & 0.3 & 6.8 & 56.9 & 102.0 & 12.7 & 9.2 \\
\hline Cape Verde & 4.4 & 2.7 & -1.2 & -6.8 & 27.7 & 13.9 & 5.4 & 4.0 \\
\hline Comoros & 0.3 & -3.2 & -9.8 & -7.5 & 9.9 & 17.5 & 7.6 & 3.6 \\
\hline Egypt & 2.8 & 2.2 & -5.8 & 2.1 & 3.1 & 22.1 & 12.8 & 10.8 \\
\hline Lesotho & 1.3 & 4.7 & 3.4 & -9.8 & 15.4 & 42.2 & 13.8 & 8.1 \\
\hline Libya & NA & NA & -1.8 & NA & 23.7 & NA & NA & NA \\
\hline Morocco & 2.0 & 0.4 & -5.4 & -1.4 & 1.5 & 11.7 & 7.2 & 3.7 \\
\hline Namibia & -1.8 & 0.8 & NA & 3.4 & NA & 6.0 & 13.6 & 9.0 \\
\hline Seychelles & 2.6 & 1.4 & -13.6 & -7.9 & 6.2 & 5.7 & 4.2 & 1.6 \\
\hline Swaziland & 3.3 & -0.2 & -6.5 & -0.1 & 20.2 & 25.3 & 10.5 & 11.2 \\
\hline Tunisia & 0.6 & 2.7 & -4.8 & -4.5 & 6.2 & 8.0 & 8.4 & 4.9 \\
\hline Zimbabwe & -0.1 & 0.0 & -2.0 & -4.8 & 1.8 & 4.3 & 12.4 & 22.4 \\
\hline
\end{tabular}


Table 5 (continued): GDP growth, current account, international reserves, and inflation in African countries by exchange rate regime, 1980-1998.

\begin{tabular}{|c|c|c|c|c|c|c|c|c|}
\hline \multirow[t]{2}{*}{ Country/regime 1999} & \multicolumn{2}{|c|}{$\begin{array}{c}\text { Growth of per capita GDP } \\
\text { (annual \%) }\end{array}$} & \multicolumn{2}{|c|}{$\begin{array}{c}\text { Current account balance } \\
(\% \text { GDP })\end{array}$} & \multicolumn{2}{|c|}{$\begin{array}{l}\text { Net international } \\
\text { reserves (\% GDP) }\end{array}$} & \multicolumn{2}{|c|}{$\begin{array}{c}\text { Inflation (average \% } \\
\text { change, GDP deflator) }\end{array}$} \\
\hline & $1980-89$ & $1990-98$ & $1980-89$ & $1990-98$ & $1980-89$ & $1990-98$ & $1980-89$ & $1990-98$ \\
\hline \multicolumn{9}{|c|}{ Group III. Independent float } \\
\hline Algeria & 0.0 & -1.0 & -0.7 & 3.7 & 4.2 & 6.9 & 7.9 & 23.3 \\
\hline Angola & 0.8 & -3.2 & -0.6 & -4.3 & NA & 4.9 & 4.2 & 1254.1 \\
\hline Burundi & 1.6 & -5.6 & -4.5 & -4.0 & 5.3 & 14.7 & 4.3 & 11.1 \\
\hline Congo, Dem. Rep. & -1.2 & -8.4 & -4.4 & -8.4 & 1.8 & 1.7 & 63.8 & 4010.7 \\
\hline Eritrea & NA & 2.4 & NA & -5.6 & NA & NA & NA & 11.2 \\
\hline Ethiopia & -2.1 & 2.6 & -5.4 & -6.4 & 2.2 & 7.2 & 5.4 & 8.2 \\
\hline Gambia & 0.0 & -1.0 & -5.1 & -0.9 & 4.5 & 24.5 & 16.6 & 5.3 \\
\hline Ghana & -0.7 & 1.5 & -2.7 & -5.2 & 5.6 & 7.8 & 47.2 & 27.1 \\
\hline Guinea & 1.7 & 1.5 & -6.2 & -5.5 & NA & 2.8 & 24.0 & 9.9 \\
\hline Kenya & 0.5 & -0.5 & -4.9 & -2.2 & 4.8 & 5.2 & 9.3 & 14.6 \\
\hline Liberia & NA & NA & -0.9 & NA & 0.5 & NA & NA & NA \\
\hline Madagascar & -1.9 & -1.6 & -7.2 & -7.4 & 3.6 & 4.4 & 18.6 & 19.1 \\
\hline Malawi & -0.8 & 1.0 & -9.0 & -15.4 & 4.5 & 7.0 & 15.3 & 29.0 \\
\hline Mauritania & -2.8 & 1.3 & -16.4 & -1.8 & 10.6 & 9.4 & 9.8 & 5.1 \\
\hline Mauritius & 5.0 & 3.8 & -3.4 & -1.7 & 9.3 & 22.5 & 9.6 & 6.7 \\
\hline Mozambique & -2.6 & 3.2 & -12.6 & -16.0 & 4.3 & 10.9 & 41.7 & 38.2 \\
\hline Nigeria & -2.3 & -0.3 & -1.6 & 0.9 & 6.0 & 11.3 & 18.9 & 33.9 \\
\hline Rwanda & -0.7 & -4.2 & -4.4 & -3.4 & 8.3 & 5.8 & 4.2 & 16.3 \\
\hline São Tome and Príncipe & -1.0 & -1.0 & -33.9 & -24.1 & NA & 18.6 & 30.2 & 53.4 \\
\hline Sierra Leone & -2.1 & -7.2 & -3.3 & -6.4 & 1.0 & 3.4 & 59.2 & 43.4 \\
\hline Somalia & NA & NA & -15.5 & NA & 1.4 & NA & NA & NA \\
\hline South Africa & -1.6 & -0.2 & 0.8 & 0.1 & 0.7 & 1.5 & 15.1 & 11.4 \\
\hline Sudan & -2.1 & 5.6 & -5.7 & -17.6 & 0.2 & 0.8 & 40.0 & 72.5 \\
\hline Tanzania & 0.7 & 0.0 & -7.0 & -13.0 & 1.3 & 6.4 & 31.3 & 24.0 \\
\hline Uganda & -0.1 & 3.9 & -4.6 & -9.9 & 1.6 & 6.2 & 116.5 & 20.1 \\
\hline Zambia & -2.1 & -1.7 & -12.2 & -13.6 & 3.3 & 5.8 & 39.0 & 75.0 \\
\hline
\end{tabular}

Sources: World Bank, World Development Indicators 2000; Fischer (2001); Mussa et al. (2000).

The 'hard peg' category includes regimes with a currency board or arrangements with no special legal tender; the 'soft peg' category includes other conventional fixed pegs, pegged rates in horizontal bands, crawling pegs, and rates with crawling bands; the 'independent floats' category includes independently floating and managed float with no pre-announced exchange rate path.

* The growth rate of per capita GDP is the time trend obtained from an OLS regression of log per capita GDP on time. 
Table 6: Exchange rates and trade by exchange rate regime, 1980-1998

\begin{tabular}{|c|c|c|c|c|c|c|c|c|}
\hline \multirow[t]{2}{*}{$\begin{array}{l}\text { Countries/regime } \\
1999\end{array}$} & \multicolumn{2}{|c|}{$\begin{array}{c}\text { Nominal exchange } \\
\text { rate } \\
\text { (nat. curr. / US \$) }\end{array}$} & \multicolumn{2}{|c|}{$\begin{array}{c}\text { Real exchange } \\
\text { rate } \\
\text { (index } \\
1995=100)^{*}\end{array}$} & \multicolumn{2}{|c|}{$\begin{array}{l}\text { Exports (\% } \\
\text { GDP) }\end{array}$} & \multicolumn{2}{|c|}{$\begin{array}{c}\text { Average trade (\% } \\
\text { GDP)** }\end{array}$} \\
\hline & $1980-89$ & $1990-98$ & $\begin{array}{r}1980- \\
89\end{array}$ & $\begin{array}{r}1990- \\
98\end{array}$ & $\begin{array}{r}1980- \\
89\end{array}$ & $\begin{array}{r}1990- \\
98\end{array}$ & $1980-89$ & $1990-98$ \\
\hline \multicolumn{9}{|c|}{ Group I. Hard pegs } \\
\hline Benin & 334.3 & 426.9 & NA & 100.7 & 26.2 & 24.5 & 33.2 & 29.0 \\
\hline Burkina Faso & 334.3 & 426.9 & 140.4 & 118.0 & 10.4 & 12.1 & 20.7 & 19.6 \\
\hline Cameroon & 334.3 & 426.9 & 113.1 & 112.7 & 26.4 & 22.2 & 26.3 & 20.8 \\
\hline $\begin{array}{l}\text { Central African } \\
\text { Republic }\end{array}$ & 334.3 & 426.9 & 154.3 & 111.5 & 20.5 & 16.7 & 26.5 & 20.8 \\
\hline Chad & 334.3 & 426.9 & 132.9 & 116.7 & 14.3 & 15.8 & 21.0 & 23.1 \\
\hline Congo, Rep. & 334.3 & 426.9 & 91.3 & 98.8 & 52.0 & 57.4 & 52.3 & 60.7 \\
\hline Côte d'Ivoire & 334.3 & 426.9 & 117.6 & 109.7 & 37.1 & 38.2 & 35.5 & 35.5 \\
\hline Djibouti & 177.7 & 177.7 & NA & NA & NA & 44.9 & NA & 56.6 \\
\hline Equatorial Guinea & 334.3 & 426.9 & NA & NA & 35.9 & 59.1 & 50.2 & 82.2 \\
\hline Gabon & 334.3 & 426.9 & 152.3 & 118.8 & 53.3 & 53.8 & 48.5 & 45.0 \\
\hline Guinea-Bissau & 6.3 & 267.5 & 146.9 & 112.5 & 9.9 & 12.0 & 26.4 & 24.6 \\
\hline Mali & 334.3 & 426.9 & 152.6 & 116.6 & 15.8 & 20.0 & 24.6 & 27.6 \\
\hline Niger & 334.3 & 426.9 & 183.7 & 113.9 & 21.0 & 16.1 & 25.0 & 19.1 \\
\hline Senegal & 334.3 & 426.9 & 136.8 & 113.3 & 28.7 & 29.6 & 34.7 & 32.7 \\
\hline Togo & 334.3 & 426.9 & 130.5 & 106.3 & 46.1 & 31.6 & 49.7 & 35.3 \\
\hline \multicolumn{9}{|c|}{ Group II. Soft pegs } \\
\hline Botswana & 1.4 & 2.8 & 99.2 & 93.4 & 58.9 & 48.3 & 52.6 & 43.7 \\
\hline Cape Verde & 69.8 & 80.3 & 77.9 & 94.5 & 15.5 & 17.4 & 30.0 & 34.7 \\
\hline Comoros & 334.3 & 350.8 & NA & NA & 14.7 & 18.5 & 31.3 & 30.1 \\
\hline Egypt & 0.7 & 3.1 & 153.1 & 98.1 & 22.2 & 23.0 & 28.8 & 26.0 \\
\hline Lesotho & 1.7 & 3.7 & 96.3 & 95.8 & 15.6 & 23.0 & 75.0 & 74.9 \\
\hline Libya & 0.3 & 0.3 & $\mathrm{NA}$ & NA & 54.7 & NA & 44.5 & NA \\
\hline Morocco & 7.5 & 8.9 & 95.7 & 91.5 & 17.8 & 19.1 & 23.2 & 23.4 \\
\hline Namibia & 1.7 & 3.7 & 104.8 & 93.0 & 58.6 & 53.8 & 62.2 & 57.3 \\
\hline Seychelles & 6.3 & 5.1 & 90.2 & 94.4 & 62.1 & 59.7 & 63.3 & 63.9 \\
\hline Swaziland & 1.7 & 3.7 & 101.6 & 91.4 & 70.7 & 83.0 & 77.5 & 85.2 \\
\hline Tunisia & 0.7 & 1.0 & 91.4 & 93.3 & 36.9 & 42.4 & 40.0 & 44.7 \\
\hline Zimbabwe & 1.3 & 8.9 & 156.7 & 96.3 & 21.4 & 33.1 & 21.8 & 34.6 \\
\hline
\end{tabular}


Table 6 (continued): Exchange rates and trade by exchange rate regime, 1980-1998

\begin{tabular}{|c|c|c|c|c|c|c|c|c|}
\hline \multirow[t]{2}{*}{$\begin{array}{l}\text { Countries/regime } \\
1999\end{array}$} & \multicolumn{2}{|c|}{$\begin{array}{c}\text { Nominal exchange } \\
\text { rate } \\
\text { (nat. curr. / US \$) }\end{array}$} & \multicolumn{2}{|c|}{$\begin{array}{c}\text { Real exchange } \\
\text { rate } \\
\text { (index 1995 = } \\
100)^{*}\end{array}$} & \multicolumn{2}{|c|}{$\begin{array}{l}\text { Exports }(\% \\
\text { GDP) }\end{array}$} & \multicolumn{2}{|c|}{$\begin{array}{l}\text { Average trade (\% } \\
\text { GDP)** }\end{array}$} \\
\hline & $1980-89$ & $1990-98$ & $\begin{array}{r}1980- \\
89\end{array}$ & $\begin{array}{r}1990- \\
98\end{array}$ & $\begin{array}{r}1980- \\
89\end{array}$ & $\begin{array}{r}1990- \\
98\end{array}$ & $1980-89$ & $90-98$ \\
\hline \multicolumn{9}{|c|}{ Group III. Independent floats } \\
\hline Algeria & 5.1 & 36.3 & 245.1 & 117.2 & 23.8 & 26.0 & 23.0 & 25.4 \\
\hline Angola & 0.0 & 83633.9 & NA & 55.1 & 34.7 & 59.2 & 30.2 & 56.9 \\
\hline Burundi & 114.0 & 267.7 & 135.2 & 96.0 & 10.4 & 9.2 & 17.1 & 16.8 \\
\hline Congo, Dem. Rep. & 0.0 & 1370.2 & 220.9 & 120.2 & 21.4 & 22.6 & 21.8 & 21.8 \\
\hline Eritrea & NA & NA & NA & NA & NA & 27.8 & NA & 54.1 \\
\hline Ethiopia & 2.1 & 4.9 & 189.0 & 139.2 & 9.3 & 10.5 & 13.0 & 15.1 \\
\hline Gambia & 4.4 & 9.4 & 107.3 & 96.9 & 47.8 & 53.7 & 54.4 & 60.8 \\
\hline Ghana & 82.3 & 1104.3 & 589.4 & 108.6 & 11.2 & 21.3 & 12.7 & 26.7 \\
\hline Guinea & 196.2 & 952.9 & NA & NA & 29.7 & 22.3 & 29.5 & 23.9 \\
\hline Kenya & 14.3 & 47.1 & 103.9 & 92.3 & 24.7 & 31.4 & 26.9 & 32.7 \\
\hline Liberia & 1.0 & 1.0 & NA & NA & 47.3 & NA & 46.0 & NA \\
\hline Madagascar & 725.8 & 3226.0 & 178.6 & 106.1 & 13.6 & 19.6 & 17.2 & 23.5 \\
\hline Malawi & 1.6 & 11.2 & 146.6 & 130.1 & 23.9 & 24.8 & 27.3 & 31.2 \\
\hline Mauritania & 64.8 & 122.4 & 128.9 & 110.9 & 42.2 & 42.8 & 52.9 & 48.4 \\
\hline Mauritius & 12.3 & 18.0 & 98.7 & 93.9 & 54.6 & 62.0 & 56.2 & 64.1 \\
\hline Mozambique & 183.2 & 6503.2 & 218.4 & 116.3 & 6.8 & 12.8 & 15.9 & 26.0 \\
\hline Nigeria & 2.2 & 18.5 & 117.9 & 79.8 & 21.4 & 40.9 & 20.9 & 38.7 \\
\hline Rwanda & 89.8 & 208.5 & 123.8 & 100.3 & 10.4 & 6.0 & 15.5 & 16.1 \\
\hline $\begin{array}{l}\text { São Tome and } \\
\text { Príncipe }\end{array}$ & 54.9 & 1250.6 & NA & NA & 29.8 & 23.4 & 56.2 & 55.9 \\
\hline Sierra Leone & 15.5 & 702.4 & 125.4 & 94.4 & 11.5 & 23.1 & 14.0 & 23.3 \\
\hline Somalia & 93.7 & NA & NA & NA & 15.5 & 9.8 & 33.0 & 23.8 \\
\hline South Africa & 1.7 & 3.7 & 96.7 & 94.3 & 28.3 & 23.3 & 25.9 & 21.9 \\
\hline Sudan & 2.1 & 663.7 & 185.1 & 195.7 & 8.2 & NA & 12.8 & NA \\
\hline Tanzania & 40.9 & 450.9 & 255.9 & 106.7 & 10.0 & 16.7 & 19.5 & 26.6 \\
\hline Uganda & 39.9 & 978.8 & 334.5 & 88.9 & 11.6 & 9.6 & 14.7 & 15.4 \\
\hline Zambia & 4.8 & 737.5 & 79.7 & 100.7 & 34.4 & 34.0 & 35.4 & 36.9 \\
\hline
\end{tabular}

Source: World Development Indicators 2000.

* The real exchange rate is computed as: (country's CPI)/(USA's CPI * Official exchange rate).

** Average trade is the average of exports and imports as \% of GDP. 
Table 7: Exchange rate regimes and macroeconomic performance: Percentage of improved performance between the 19801989 and the 1990-1998 period

\begin{tabular}{|c|c|c|c|c|c|c|c|c|}
\hline \multirow[t]{2}{*}{ Category } & & \multicolumn{2}{|c|}{ Growth in $1990-98$} & \multicolumn{2}{|c|}{ Inflation in $1990-98$} & \multirow{2}{*}{$\begin{array}{c}\text { Trade } \\
\text { (higher) }\end{array}$} & \multirow{2}{*}{$\begin{array}{l}\text { Current } \\
\text { account } \\
\text { balance } \\
\text { (improve) }\end{array}$} & \multirow{2}{*}{$\begin{array}{l}\text { Reserves } \\
\text { (higher) }\end{array}$} \\
\hline & & $\begin{array}{l}\text { Positive } \\
\text { growth }\end{array}$ & $\begin{array}{l}\text { Higher than } \\
1980-89\end{array}$ & Lower & Below 10\% & & & \\
\hline Hard pegs & & $50.0 \%$ & $35.7 \%$ & $28.6 \%$ & $92.9 \%$ & $28.6 \%$ & $50.0 \%$ & $57.1 \%$ \\
\hline Soft pegs & & $81.8 \%$ & $36.4 \%$ & $81.8 \%$ & $72.7 \%$ & $54.5 \%$ & $60.0 \%$ & $80.0 \%$ \\
\hline \multirow{2}{*}{$\begin{array}{l}\text { Independent } \\
\text { Floats }\end{array}$} & Group & $47.8 \%$ & $30.4 \%$ & $43.5 \%$ & $21.7 \%$ & $72.7 \%$ & $47.8 \%$ & $85.0 \%$ \\
\hline & $\begin{array}{l}\text { (without } \\
\text { conflict } \\
\text { countries) }\end{array}$ & $(57.9) \%$ & $(36.8)$ & $(50.0 \%)$ & $(26.3)$ & $(72.2 \%)$ & $(47.4 \%)$ & $(88.2 \%)$ \\
\hline \multirow{2}{*}{$\begin{array}{l}\text { Shifting } \\
\text { from soft } \\
\text { pegs to } \\
\text { independent } \\
\text { floats }\end{array}$} & Group & $53.8 \%$ & $38.5 \%$ & $23.1 \%$ & $15.4 \%$ & $83.3 \%$ & $46.2 \%$ & $90.9 \%$ \\
\hline & $\begin{array}{l}\text { (without } \\
\text { conflict } \\
\text { countries) }\end{array}$ & $70.0 \%$ & $50.0 \%$ & $(30.0 \%)$ & $(20.0 \%)$ & $(88.9 \%)$ & $(40.0 \%)$ & $(100.0 \%)$ \\
\hline
\end{tabular}

This table summarizes information from Table 5 and 6 . Table A1 gives the information of countries that shifted from soft pegs to independent float used in this table. Djibouti, Eritrea, Liberia, Libya, and Somalia are not included in this summary table due to missing data.

"Conflict countries" in the floating regimes category are Angola, Burundi, Rwanda, and Sierra Leone (and Somalia which is excluded due to lack of data). 
Table 8: GDP growth, exports, and inflation in CFA countries, 1980-1998

\begin{tabular}{|c|c|c|c|c|c|c|c|c|c|}
\hline \multirow[t]{2}{*}{ Country } & \multicolumn{3}{|c|}{ Growth of per capita GDP* } & \multicolumn{3}{|c|}{ Exports (\% GDP) } & \multicolumn{3}{|c|}{$\begin{array}{l}\text { Inflation (average annual change } \\
\text { of CPI index) }\end{array}$} \\
\hline & $1980-89$ & $1990-94$ & $1995-98$ & $1980-89$ & $1990-94$ & $1995-98$ & $1980-89$ & $1990-94$ & $1995-98$ \\
\hline Benin & -0.4 & 0.9 & 2.2 & 26.2 & 24.1 & 25.1 & NA & 19.5 & 7.1 \\
\hline Burkina Faso & 1.4 & -0.1 & 2.7 & 10.4 & 11.9 & 12.2 & 1.7 & 5.1 & 5.2 \\
\hline Cameroon & 1.8 & -6.4 & 1.8 & 26.4 & 20.0 & 25.0 & 9.0 & 6.6 & 6.7 \\
\hline Central African Republic & -0.9 & -3.0 & 1.3 & 20.5 & 15.4 & 18.3 & 3.7 & 3.5 & 5.7 \\
\hline Chad & 4.0 & -1.4 & 1.2 & 14.3 & 13.2 & 19.1 & 3.0 & 6.9 & 9.8 \\
\hline Congo & 2.7 & -2.9 & 0.1 & 52.0 & 49.8 & 66.9 & 7.6 & 11.6 & 10.6 \\
\hline Côte d'Ivoire & -2.6 & -2.9 & 3.7 & 37.1 & 33.1 & 44.7 & 5.9 & 6.7 & 6.4 \\
\hline Equatorial Guinea & -1.9 & 2.6 & 31.7 & 35.9 & 39.3 & 83.9 & NA & NA & NA \\
\hline Gabon & -1.5 & -0.1 & 1.7 & 53.3 & 50.0 & 58.5 & 5.8 & 4.6 & 4.8 \\
\hline Guinea-Bissau & 2.9 & 1.4 & -5.6 & 9.9 & 10.0 & 14.5 & 70.5 & 44.7 & 38.3 \\
\hline Mali & -1.5 & -1.4 & 2.4 & 15.8 & 17.9 & 22.5 & -0.1 & 3.8 & 6.0 \\
\hline Niger & -2.9 & -3.2 & 0.9 & 21.0 & 15.6 & 16.6 & 2.8 & 4.3 & 5.8 \\
\hline Senegal & 0.3 & -1.3 & 2.4 & 28.7 & 26.1 & 33.9 & 6.7 & 6.0 & 3.4 \\
\hline Togo & -1.7 & -4.0 & 2.1 & 46.1 & 29.8 & 34.0 & 4.2 & 8.2 & 7.6 \\
\hline Sample** & -0.4 & -2.8 & 2.3 & 31.7 & 27.9 & 35.6 & 6.1 & 6.2 & 6.3 \\
\hline
\end{tabular}

Source: World Development Indicators 2000.

* The growth rate in a period is the simple average of annual growth rates of real per capita GDP (constant 1995 \$).

** The sample growth rate of per capita GDP is the average growth rate of the population-weighted real per capita GDP. The sample average export/GDP ratio and inflation rate are weighted by real GDP. 
Table 9: GDP growth, exports, and inflation in SADC countries, 1980-1998

\begin{tabular}{|c|c|c|c|c|c|c|c|c|c|}
\hline \multirow[t]{2}{*}{ Country } & \multicolumn{3}{|c|}{ Growth of per capita GDP* } & \multicolumn{3}{|c|}{ Exports (\% GDP) } & \multicolumn{3}{|c|}{ Inflation (average annual change of CPI index) } \\
\hline & $1980-89$ & $1990-94$ & $1995-98$ & $1980-89$ & $1990-94$ & $1995-98$ & $1980-89$ & $1990-94$ & $1995-98$ \\
\hline Angola & -0.1 & -8.6 & 5.4 & 34.7 & 55.4 & 63.9 & NA & 876.1 & 3174.5 \\
\hline Botswana & 6.7 & 1.7 & 2.5 & 58.9 & 50.4 & 45.6 & 10.5 & 12.8 & 9.0 \\
\hline Lesotho & 2.0 & 2.6 & 4.3 & 15.6 & 18.8 & 28.2 & 13.6 & 13.6 & 9.3 \\
\hline Mozambique & -1.2 & 0.9 & 6.1 & 6.8 & 12.1 & 13.7 & 45.1 & 46.2 & 35.0 \\
\hline Mauritius & 5.0 & 4.2 & 4.3 & 54.6 & 61.0 & 63.3 & 7.7 & 8.6 & 6.6 \\
\hline Malawi & -1.3 & -1.6 & 5.3 & 23.9 & 23.4 & 26.6 & 16.8 & 21.1 & 40.0 \\
\hline Namibia & -1.8 & 1.3 & -0.2 & 58.6 & 52.7 & 55.2 & 13.0 & 12.2 & 8.3 \\
\hline Swaziland & 3.1 & 0.7 & -0.1 & 70.7 & 79.8 & 86.9 & 14.7 & 11.1 & 8.5 \\
\hline Tanzania & 0.7 & -0.2 & 0.8 & 10.0 & 14.0 & 20.1 & 30.1 & 28.9 & 19.6 \\
\hline South Africa & -0.9 & -1.9 & 0.6 & 28.3 & 22.4 & 24.5 & 14.7 & 12.5 & 7.8 \\
\hline Zambia & -1.8 & -2.7 & -1.1 & 34.4 & 34.7 & 33.1 & 69.3 & 122.2 & 35.1 \\
\hline Zimbabwe & 0.8 & -0.3 & 1.5 & 21.4 & 27.9 & 39.6 & 13.6 & 26.5 & 23.6 \\
\hline Sample** & -2.9 & -2.1 & 0.6 & 29.4 & 25.7 & 28.5 & 13.8 & 12.9 & 29.1 \\
\hline
\end{tabular}

Source: World Bank, World Development Indicators 2000.

* The growth rate in a period is the simple average of annual growth rates of real per capita GDP (constant 1995 \$).

** The sample growth rate of per capita GDP is the average growth rate of the population-weighted real per capita GDP. The sample average export/GDP ratio and inflation rate are weighted by real GDP. Excluding Angola, the sample average inflation rate for 199598 is $9.3 \%$. 
Table 10: Indicators of capital flight from 30 sub-Saharan African countries, 1970-1996

\begin{tabular}{|c|c|c|c|c|c|c|}
\hline \multirow[t]{3}{*}{ Country } & \multirow{3}{*}{$\begin{array}{r}G D P / \text { capita } 1996 \\
\text { (I) }\end{array}$} & \multirow{3}{*}{$\begin{array}{l}\text { Real capital flight } \\
\text { (mill. } 1996 \text { \$) (II) }\end{array}$} & \multicolumn{3}{|c|}{ Cumulative capital stock } & \multirow{3}{*}{$\begin{array}{l}\text { Net external } \\
\text { Assets }^{a} \\
\quad(V I)\end{array}$} \\
\hline & & & (III) & (IV) & $(V)$ & \\
\hline & & & Stock (million 1996 \$) & $\%$ of GDP & Per capita $\$$ & \\
\hline Angola & 673 & 17032.5 & 20405.0 & 267.8 & 1803 & 9179.9 \\
\hline Benin* & 392 & -3457.4 & -6003.8 & -271.9 & -1067 & -7598.1 \\
\hline Burkina Faso & 201 & 1265.5 & 1896.6 & 96.5 & 194 & 700.4 \\
\hline Burundi & 143 & 818.9 & 980.9 & 108.9 & 156 & -146.0 \\
\hline Cameroon & 672 & 13099.4 & 16906 & 185.6 & 1248 & 7364.4 \\
\hline Central African Republic & 281 & 250.2 & 459.0 & 50.8 & 143 & -482.1 \\
\hline Congo DRC & 130 & 10035.4 & 19199.9 & 327.1 & 424 & 6373.5 \\
\hline Congo Rep. & 959 & 459.2 & 1254.0 & 49.6 & 476 & -3986.6 \\
\hline Côte d'Ivoire & 770 & 23371.0 & 34745.5 & 324.7 & 2502 & 15221.9 \\
\hline Ethiopia & 103 & 5522.8 & 8017.9 & 133.4 & 138 & -2060.7 \\
\hline Gabon* & 5139 & 2988.7 & 5028.1 & 87.0 & 4469 & 717.7 \\
\hline Ghana & 395 & 407.3 & 289.3 & 4.2 & 17 & -6152.9 \\
\hline Guinea & 586 & 342.8 & 434.2 & 11.0 & 64 & -2806.1 \\
\hline Kenya & 330 & 815.1 & 2472.6 & 26.8 & 89 & -4458.4 \\
\hline Madagascar & 291 & 1649.0 & 1577.5 & 39.5 & 115 & -2568.3 \\
\hline Malawi & 132 & 705.1 & 1174.8 & 93.8 & 124 & -971.3 \\
\hline Mali & 266 & -1203.6 & -1527.2 & -57.5 & -153 & -4533.2 \\
\hline Mauritania & 469 & 1130.8 & 1830.0 & 167.4 & 786 & -572.2 \\
\hline Mauritius* & 3792 & -267.8 & 465.9 & 10.8 & 411 & -1351.7 \\
\hline Mozambique & 175 & 5311.3 & 6206.9 & 218.4 & 382 & -1359.4 \\
\hline Niger & 210 & -3153.1 & -4768.9 & -247.7 & -521 & -6392.1 \\
\hline Nigeria & 308 & 86761.9 & 129661.0 & 367.3 & 1132 & 98254.4 \\
\hline Rwanda & 209 & 2115.9 & 3513.9 & 249.9 & 522 & 2470.8 \\
\hline Senegal* & 544 & -7278.1 & -9998.2 & -214.9 & -1168 & -13661.1 \\
\hline Seychelles* & 6632 & 566.5 & 1032.3 & 203.4 & 13487 & 884.3 \\
\hline Sierra Leone & 196 & 1472.8 & 2277.8 & 257.1 & 505 & 1072.7 \\
\hline Sudan & 265 & 6982.7 & 11613.7 & 161.1 & 428 & -5358.3 \\
\hline Tanzania & 191 & 1699.1 & 6203.4 & 106.3 & 203 & -1158.4 \\
\hline Uganda & 306 & 2154.9 & 3316.1 & 54.8 & 168 & -358.3 \\
\hline Zambia & 461 & 10623.5 & 13131.2 & 354.9 & 1637 & 5491.8 \\
\hline Sample & 311 & 182222.3 & 271795.4 & 172.8 & 538 & 81756.6 \\
\hline SILIC only ${ }^{b}$ & 286 & 189670.4 & 281271.1 & 201.1 & 576 & 102765.5 \\
\hline
\end{tabular}

Sources: For SILIC countries: Boyce and Ndikumana (2001), including revisions of the data for the DRC for 1990-96; For other countries: author's computations using the methodology developed in Boyce and Ndikumana (2001). The sample period varies by country depending on data availability.

* Countries with an * are not SILIC countries (per World Bank's classification as of December 1998).

${ }^{\text {a }}$ Net external assets = accumulated capital flight (with interest earning) minus stock of debt.

${ }^{b}$ Prior to 1998, Kenya was classified as SILIC. In this table, it is included in the SILIC sample statistics for comparison purposes with earlier studies on capital flight from SILIC, which included Kenya in this group (Ajayi 1997; Boyce and Ndikumana 2001). 
Table A1: Exchange rate regimes in 1991 and 1999 (grouped by the exchange rate regime in 1999)

\begin{tabular}{|c|c|c|c|c|c|}
\hline Country & $\begin{array}{l}\text { Regime } \\
1991\end{array}$ & Category 1991 & $\begin{array}{l}\text { Regime } \\
1999\end{array}$ & Category 1999 & $\begin{array}{l}\text { Currency } \\
\text { peg, } 1999\end{array}$ \\
\hline Benin & $\mathrm{NS} / \mathrm{CBA}$ & Hard peg & $\mathrm{NS} / \mathrm{CBA}$ & Hard peg & French F \\
\hline Burkina Faso & $\mathrm{NS} / \mathrm{CBA}$ & Hard peg & $\mathrm{NS} / \mathrm{CBA}$ & Hard peg & French F \\
\hline Cameroon & $\mathrm{NS} / \mathrm{CBA}$ & Hard peg & $\mathrm{NS} / \mathrm{CBA}$ & Hard peg & French F \\
\hline $\begin{array}{l}\text { Central African } \\
\text { Republic }\end{array}$ & $\mathrm{NS} / \mathrm{CBA}$ & Hard peg & $\mathrm{NS} / \mathrm{CBA}$ & Hard peg & French F \\
\hline Chad & $\mathrm{NS} / \mathrm{CBA}$ & Hard peg & $\mathrm{NS} / \mathrm{CBA}$ & Hard peg & French F \\
\hline Congo, Rep. & $\mathrm{NS} / \mathrm{CBA}$ & Hard peg & $\mathrm{NS} / \mathrm{CBA}$ & Hard peg & French F \\
\hline Côte d'Ivoire & $\mathrm{NS} / \mathrm{CBA}$ & Hard peg & $\mathrm{NS} / \mathrm{CBA}$ & Hard peg & French F \\
\hline Djibouti & $\mathrm{NS} / \mathrm{CBA}$ & Hard peg & $\mathrm{NS} / \mathrm{CBA}$ & Hard peg & French F \\
\hline Equatorial Guinea & $\mathrm{NS} / \mathrm{CBA}$ & Hard peg & $\mathrm{NS} / \mathrm{CBA}$ & Hard peg & French F \\
\hline Gabon & $\mathrm{NS} / \mathrm{CBA}$ & Hard peg & $\mathrm{NS} / \mathrm{CBA}$ & Hard peg & French F \\
\hline Guinea-Bissau & $\mathrm{CP}$ & Soft peg & $\mathrm{NS} / \mathrm{CBA}$ & Hard peg & French F \\
\hline Mali & $\mathrm{NS} / \mathrm{CBA}$ & Hard peg & $\mathrm{NS} / \mathrm{CBA}$ & Hard peg & French F \\
\hline Niger & $\mathrm{NS} / \mathrm{CBA}$ & Hard peg & $\mathrm{NS} / \mathrm{CBA}$ & Hard peg & French F \\
\hline Senegal & $\mathrm{NS} / \mathrm{CBA}$ & Hard peg & $\mathrm{NS} / \mathrm{CBA}$ & Hard peg & French F \\
\hline Togo & $\mathrm{NS} / \mathrm{CBA}$ & Hard peg & $\mathrm{NS} / \mathrm{CBA}$ & Hard peg & French F \\
\hline Botswana & $\mathrm{FP}$ & Soft peg & $\mathrm{FP}$ & Soft peg & $\begin{array}{l}\text { Basket } \\
\text { (SDR, rand) }\end{array}$ \\
\hline Cape Verde & $\mathrm{FP}$ & Soft peg & FP & Soft peg & Escudo \\
\hline Comoros & FP & Soft peg & FP & Soft peg & French F \\
\hline Egypt & $\mathrm{FP}$ & Soft peg & FP & Soft peg & USD \\
\hline Lesotho & $\mathrm{FP}$ & Soft peg & FP & Soft peg & Rand \\
\hline Libya & $\mathrm{HB}$ & Soft peg & $\mathrm{HB}$ & Soft peg & SDR \\
\hline Morocco & $\mathrm{FP}$ & Soft peg & $\mathrm{FP}$ & Soft peg & $\begin{array}{l}\text { Basket } \\
\text { (USD, SDR, } \\
\text { f) }\end{array}$ \\
\hline Namibia & $\mathrm{NS} / \mathrm{CBA}$ & Hard peg & FP & Soft peg & Rand \\
\hline Seychelles & FP & Soft peg & FP & Soft peg & $\begin{array}{l}\text { Basket (euro, } \\
\text { yen, £, USD, } \\
\text { Singapore \$, } \\
\text { rand) }\end{array}$ \\
\hline Swaziland & $\mathrm{FP}$ & Soft peg & $\mathrm{FP}$ & Soft peg & Rand \\
\hline Tunisia & $\mathrm{CP}$ & Soft peg & $\mathrm{CP}$ & Soft peg & $\mathrm{CP}$ \\
\hline Zimbabwe & FP & Soft peg & $\mathrm{FP}$ & Soft peg & USD \\
\hline Algeria & FP & Soft peg & MF & $\begin{array}{l}\text { Independent } \\
\text { float }\end{array}$ & $\mathrm{MF}$ \\
\hline Angola & FP & Soft peg & IF & $\begin{array}{l}\text { Independent } \\
\text { float }\end{array}$ & IF \\
\hline Burundi & FP & Soft peg & MF & $\begin{array}{l}\text { Independent } \\
\text { float }\end{array}$ & $\mathrm{MF}$ \\
\hline Congo, DRC & IF & $\begin{array}{l}\text { Independent } \\
\text { float }\end{array}$ & IF & $\begin{array}{l}\text { Independent } \\
\text { float }\end{array}$ & IF \\
\hline Eritrea & & & IF & $\begin{array}{l}\text { Independent } \\
\text { float }\end{array}$ & IF \\
\hline Ethiopia & FP & Soft peg & MF & $\begin{array}{l}\text { Independent } \\
\text { float }\end{array}$ & $\mathrm{MF}$ \\
\hline
\end{tabular}


Table A1 (continued): Exchange rate regimes in 1991 and 1999 (grouped by the exchange rate regime in 1999)

\begin{tabular}{|c|c|c|c|c|c|}
\hline Country & $\begin{array}{l}\text { Regime } \\
1991\end{array}$ & Category 1991 & Regime 1999 & Category 1999 & $\begin{array}{l}\text { Currency } \\
\text { peg, } 1999\end{array}$ \\
\hline Gambia & & & IF & $\begin{array}{l}\text { Independent } \\
\text { float }\end{array}$ & IF \\
\hline Ghana & IF & $\begin{array}{l}\text { Independent } \\
\text { float }\end{array}$ & IF & $\begin{array}{l}\text { Independent } \\
\text { float }\end{array}$ & IF \\
\hline Guinea & MF & $\begin{array}{l}\text { Independent } \\
\text { float }\end{array}$ & IF & $\begin{array}{l}\text { Independent } \\
\text { float }\end{array}$ & IF \\
\hline Kenya & FP & Soft peg & MF & $\begin{array}{l}\text { Independent } \\
\text { float }\end{array}$ & MF \\
\hline Liberia & FP & Soft peg & IF & $\begin{array}{l}\text { Independent } \\
\text { float }\end{array}$ & IF \\
\hline Madagascar & FP & Soft peg & IF & $\begin{array}{l}\text { Independent } \\
\text { float }\end{array}$ & IF \\
\hline Malawi & $\mathrm{FP}$ & Soft peg & MF & $\begin{array}{l}\text { Independent } \\
\text { float }\end{array}$ & MF \\
\hline Mauritania & MF & $\begin{array}{l}\text { Independent } \\
\text { float }\end{array}$ & MF & $\begin{array}{l}\text { Independent } \\
\text { float }\end{array}$ & MF \\
\hline Mauritius & FP & Soft peg & IF & $\begin{array}{l}\text { Independent } \\
\text { float }\end{array}$ & IF \\
\hline Mozambique & MF & $\begin{array}{l}\text { Independent } \\
\text { float }\end{array}$ & IF & $\begin{array}{l}\text { Independent } \\
\text { float }\end{array}$ & IF \\
\hline Nigeria & MF & $\begin{array}{l}\text { Independent } \\
\text { float }\end{array}$ & MF & $\begin{array}{l}\text { Independent } \\
\text { float }\end{array}$ & MF \\
\hline Rwanda & FP & Soft peg & IF & $\begin{array}{l}\text { Independent } \\
\text { float }\end{array}$ & IF \\
\hline $\begin{array}{l}\text { Sao Tome and } \\
\text { Principe }\end{array}$ & $\mathrm{CP}$ & Soft peg & IF & $\begin{array}{l}\text { Independent } \\
\text { float }\end{array}$ & IF \\
\hline Sierra Leone & IF & $\begin{array}{l}\text { Independent } \\
\text { float }\end{array}$ & IF & $\begin{array}{l}\text { Independent } \\
\text { float }\end{array}$ & IF \\
\hline Somalia & $\mathrm{CP}$ & Soft peg & IF & $\begin{array}{l}\text { Independent } \\
\text { float }\end{array}$ & IF \\
\hline South Africa & MF & $\begin{array}{l}\text { Independent } \\
\text { float }\end{array}$ & IF & $\begin{array}{l}\text { Independent } \\
\text { float }\end{array}$ & IF \\
\hline Sudan & FP & Soft peg & IF & $\begin{array}{l}\text { Independent } \\
\text { float }\end{array}$ & IF \\
\hline Tanzania & FP & Soft peg & IF & $\begin{array}{l}\text { Independent } \\
\text { float }\end{array}$ & IF \\
\hline Uganda & FP & Soft peg & IF & $\begin{array}{l}\text { Independent } \\
\text { float }\end{array}$ & IF \\
\hline Zambia & MF & $\begin{array}{l}\text { Independent } \\
\text { float }\end{array}$ & IF & $\begin{array}{l}\text { Independent } \\
\text { float }\end{array}$ & IF \\
\hline
\end{tabular}

Source: Fischer (2001); IMF, Annual Report on Exchange Arrangements and Exchange Restrictions 2000. Acronyms: $\mathrm{CP}=$ Crawling pegs; $\mathrm{FP}=$ other conventional fixed pegs; $\mathrm{HB}=$ pegged rate in horizontal band; $\mathrm{IF}=$ independently floating; $\mathrm{MF}=$ managed float with no pre-announced exchange rate path; $\mathrm{CB}=$ rates within crawling bands; NS = Arrangements with no separate legal tender; CBA = Currency board. 
Table A2: Controls of foreign exchange and capital account transactions in some African countries as of 1999

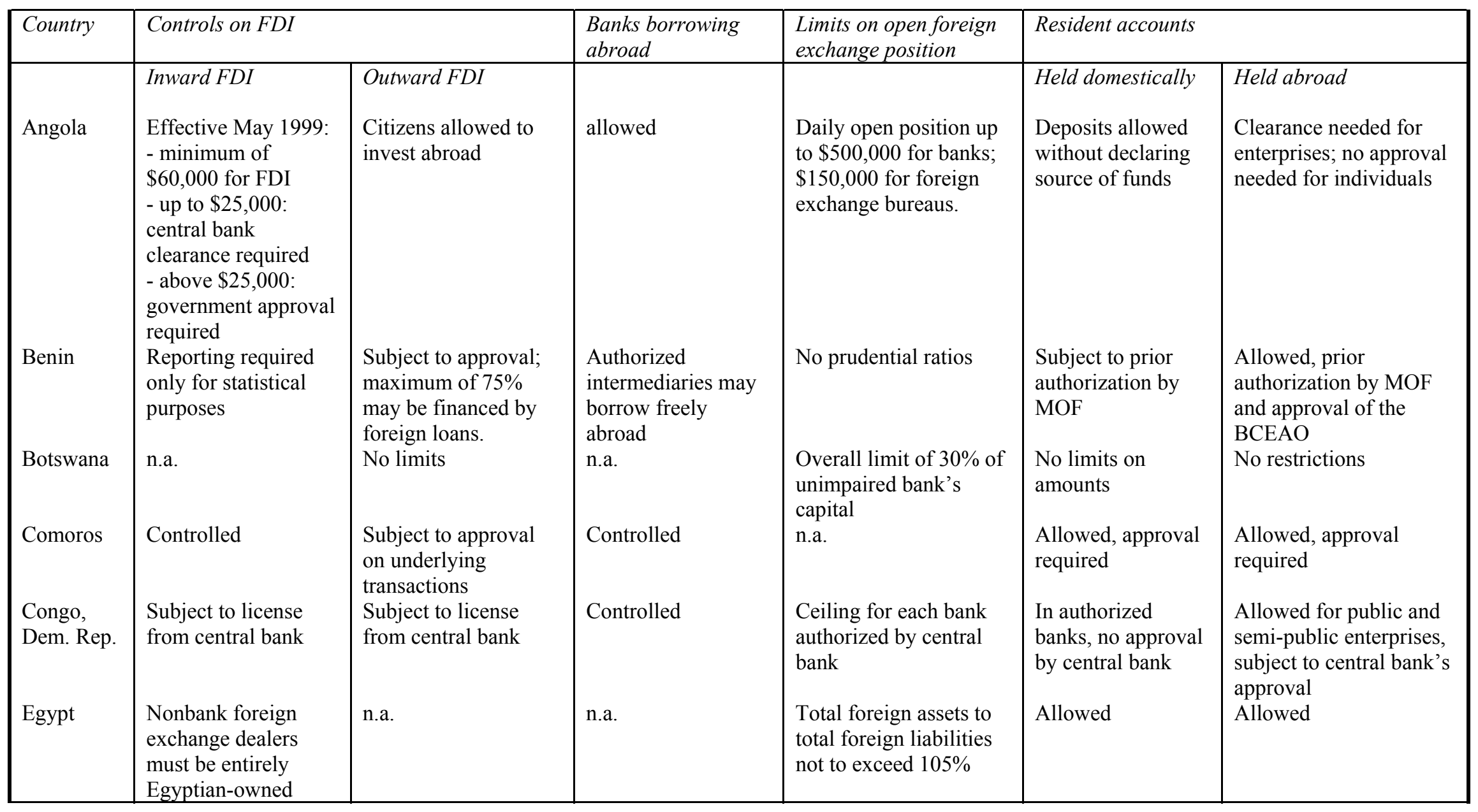


Table A2 (continued): Controls of foreign exchange and capital account transactions in some African countries (1999)

\begin{tabular}{|c|c|c|c|c|c|c|}
\hline \multirow[t]{2}{*}{ Country } & \multicolumn{2}{|l|}{ Controls on FDI } & \multirow{2}{*}{$\begin{array}{l}\text { Banks borrowing } \\
\text { abroad }\end{array}$} & \multirow{2}{*}{$\begin{array}{l}\text { Limits on open foreign } \\
\text { exchange position }\end{array}$} & \multicolumn{2}{|l|}{ Resident accounts } \\
\hline & Inward FDI & Outward FDI & & & Held domestically & Held abroad \\
\hline Ethiopia & $\begin{array}{l}\text { Foreigners can hold up to } 100 \% \\
\text { of share in any ventures, } \\
\text { excluding banking, insurance, } \\
\text { and transport; } \\
\text { Investment restricted in some } \\
\text { sectors; tax incentives for FDI. }\end{array}$ & n.a. & $\begin{array}{l}\text { Subject to central } \\
\text { bank's authorization }\end{array}$ & $\begin{array}{l}\text { Maximum } 15 \% \text { of a bank's } \\
\text { capital at end of business day } \\
\text { on each Friday }\end{array}$ & $\begin{array}{l}\text { Allowed for } \\
\text { exporters with } \\
\text { central bank's } \\
\text { approval }\end{array}$ & Not allowed \\
\hline Gabon & $\begin{array}{l}\text { Minimum national shareholding } \\
\text { of } 10 \% \text { of capital }\end{array}$ & $\begin{array}{l}\text { Must be } \\
\text { declared at } \\
\text { MOFBP }\end{array}$ & n.a. & n.a. & Not allowed & $\begin{array}{l}\text { Allowed with } \\
\text { prior approval }\end{array}$ \\
\hline Ghana & $\begin{array}{l}\text { Minimum amounts of: } \\
\text { - } \$ 10,000 \text { if joint venture with } \\
\text { Ghanaian partner } \\
\text { - } \$ 50,000 \text { when wholly foreign- } \\
\text { owned } \\
\text { - } \$ 300,000 \text { if employs at least } 10 \\
\text { Ghanaians and wholly or partly } \\
\text { foreign-owned. }\end{array}$ & $\begin{array}{l}\text { Approval on } \\
\text { the basis of } \\
\text { merit }\end{array}$ & $\begin{array}{l}\text { Allowed with prior } \\
\text { notification of the } \\
\text { central bank }\end{array}$ & $\begin{array}{l}\text { Allowed based on volume of } \\
\text { foreign exchange transactions } \\
\text { by banks; subject to periodic } \\
\text { review }\end{array}$ & Allowed & $\begin{array}{l}\text { Permitted with } \\
\text { prior approval }\end{array}$ \\
\hline Kenya & No controls & No controls & No controls & $\begin{array}{l}\text { Allowed up to } 20 \% \text { of paid-up } \\
\text { capital }\end{array}$ & No controls & No controls \\
\hline Mauritius & Controlled & n.a. & n.a. & $\begin{array}{l}\text { Daily maximum of } 15 \% \text { of } \\
\text { Tier I capital }\end{array}$ & $\begin{array}{l}\text { Allowed for } \\
\text { companies and } \\
\text { individuals }\end{array}$ & Controlled \\
\hline
\end{tabular}


Table A2 (continued): Controls of foreign exchange and capital account transactions in some African countries (1999)

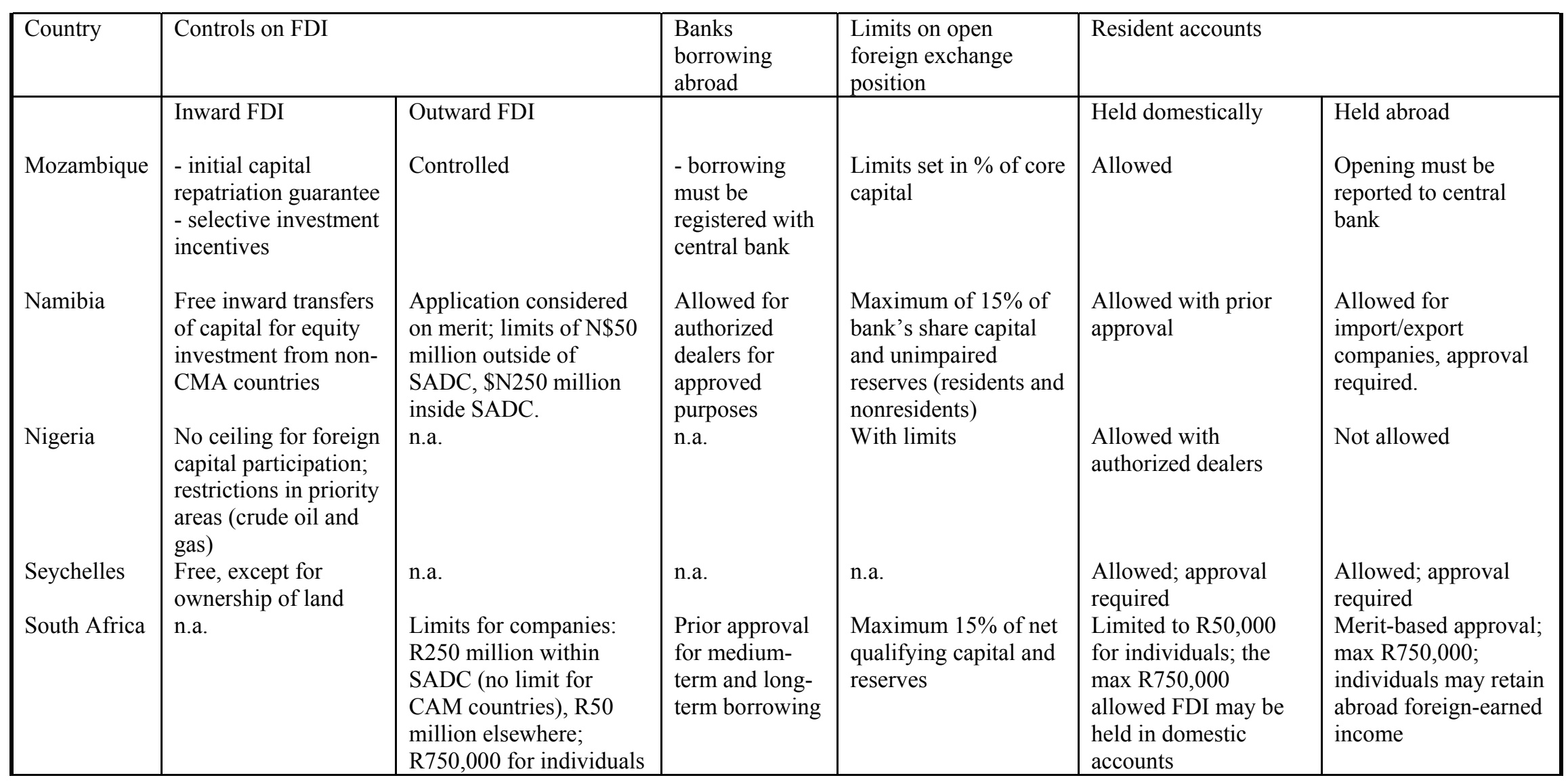


Table A2 (continued): Controls of foreign exchange and capital account transactions in some African countries (1999)

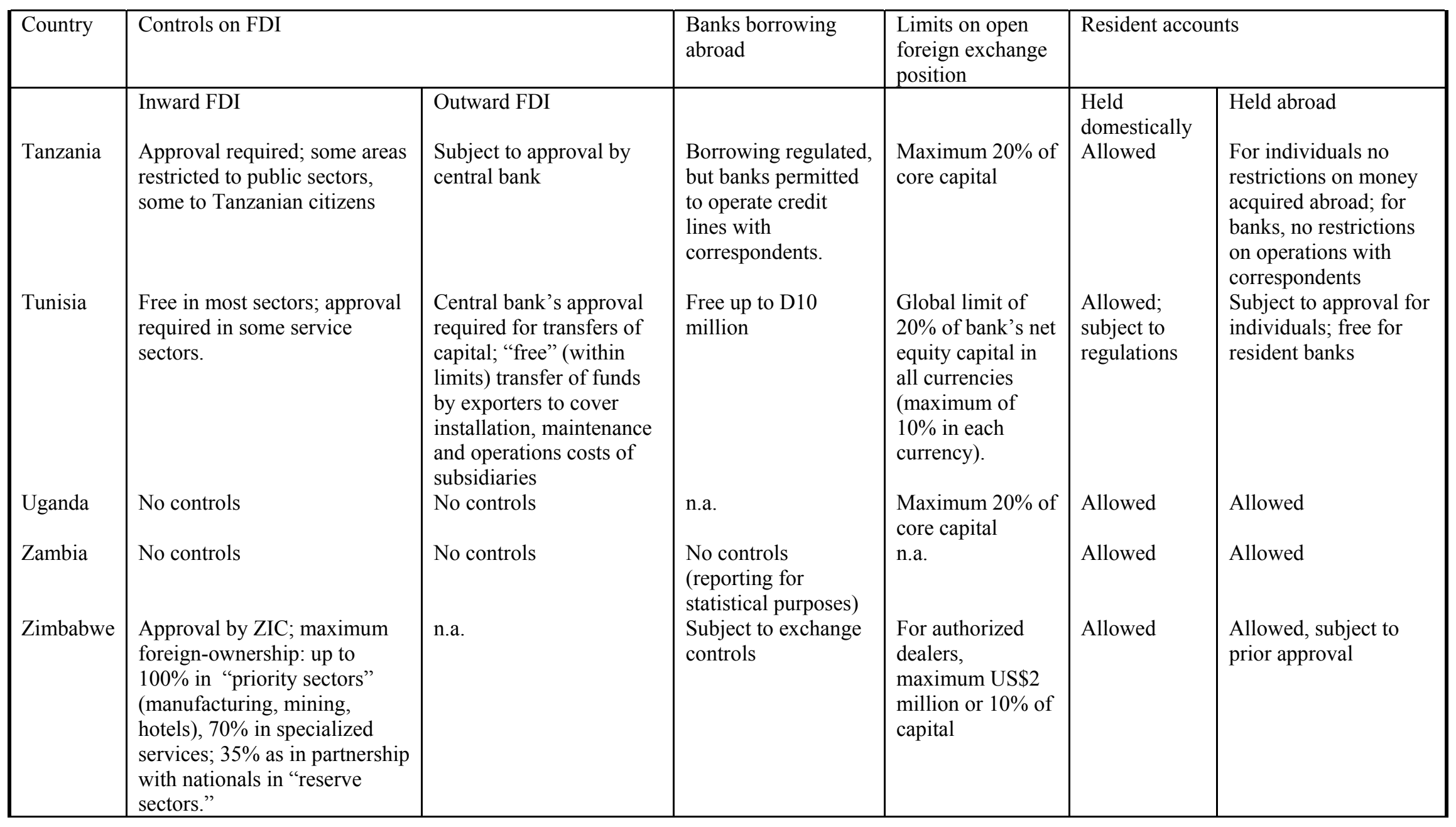

Sources: IMF, Annual Report on Exchange Arrangements and Exchange Restrictions 2000.

$\mathrm{MOF}=$ Ministry of Finance; BCEAO = Banque Centrale des Etats de l'Afrique de l'Ouest (Central Bank of West African States); CMA = Common Monetary Area (Lesotho, Namibia, South Africa, Swaziland); SADC = Southern African Development Community; ZIC = Zimbabwe Investment Center. 
Figure 1: Capital flows to Africa: volume and share in developing countries
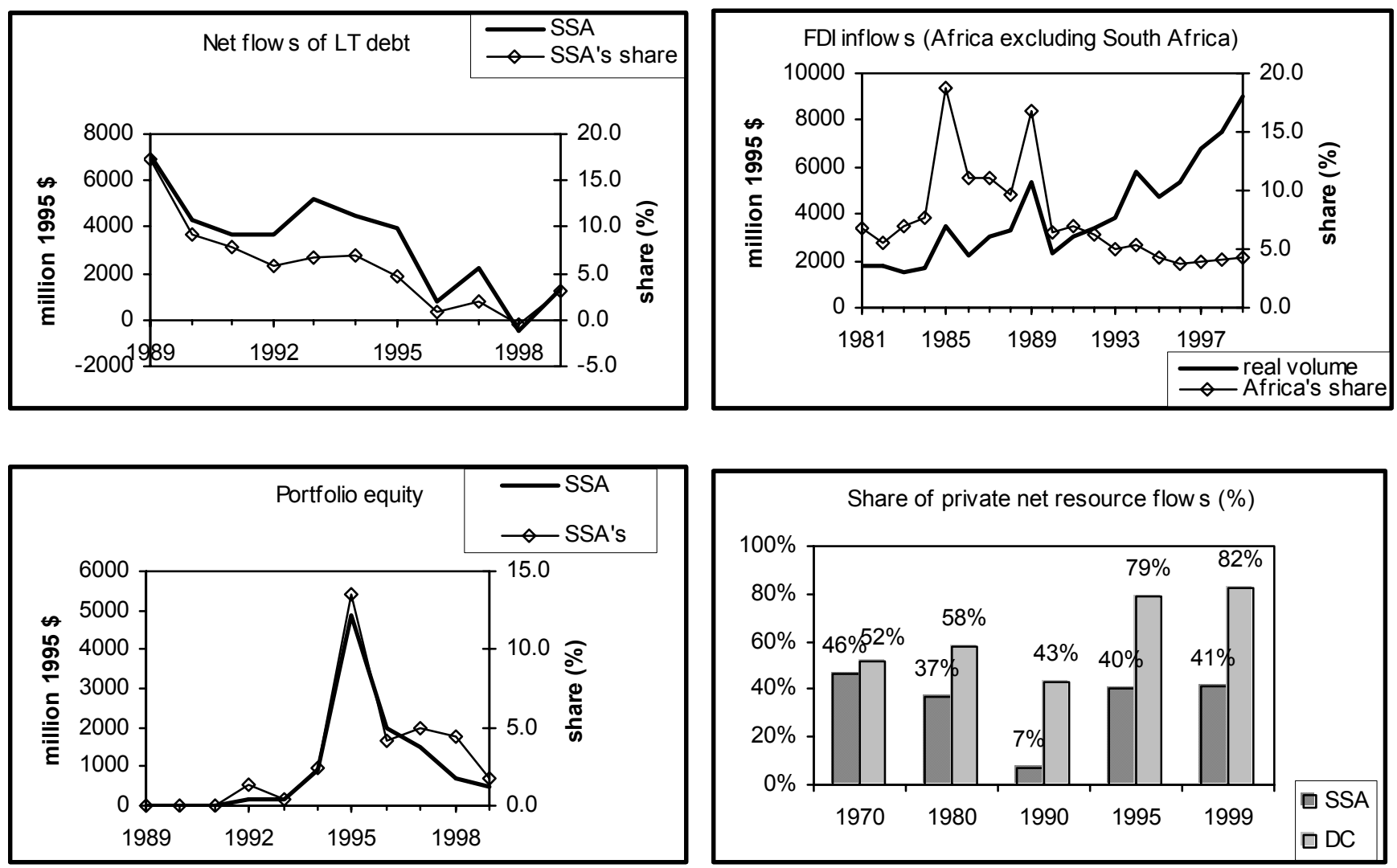

Note: SSA $=$ sub-Saharan Africa; DC $=$ Developing Countries

Source: World Bank, Global Development Finance (1997 and 2000); For FDI: UNCTAD, World Investment Report (1998, 2000) and UNCTAD (1995). Foreign Direct Investment in Africa. 
Figure 2: Rates of return on United States FDI, 1980-1997 (per cent)*
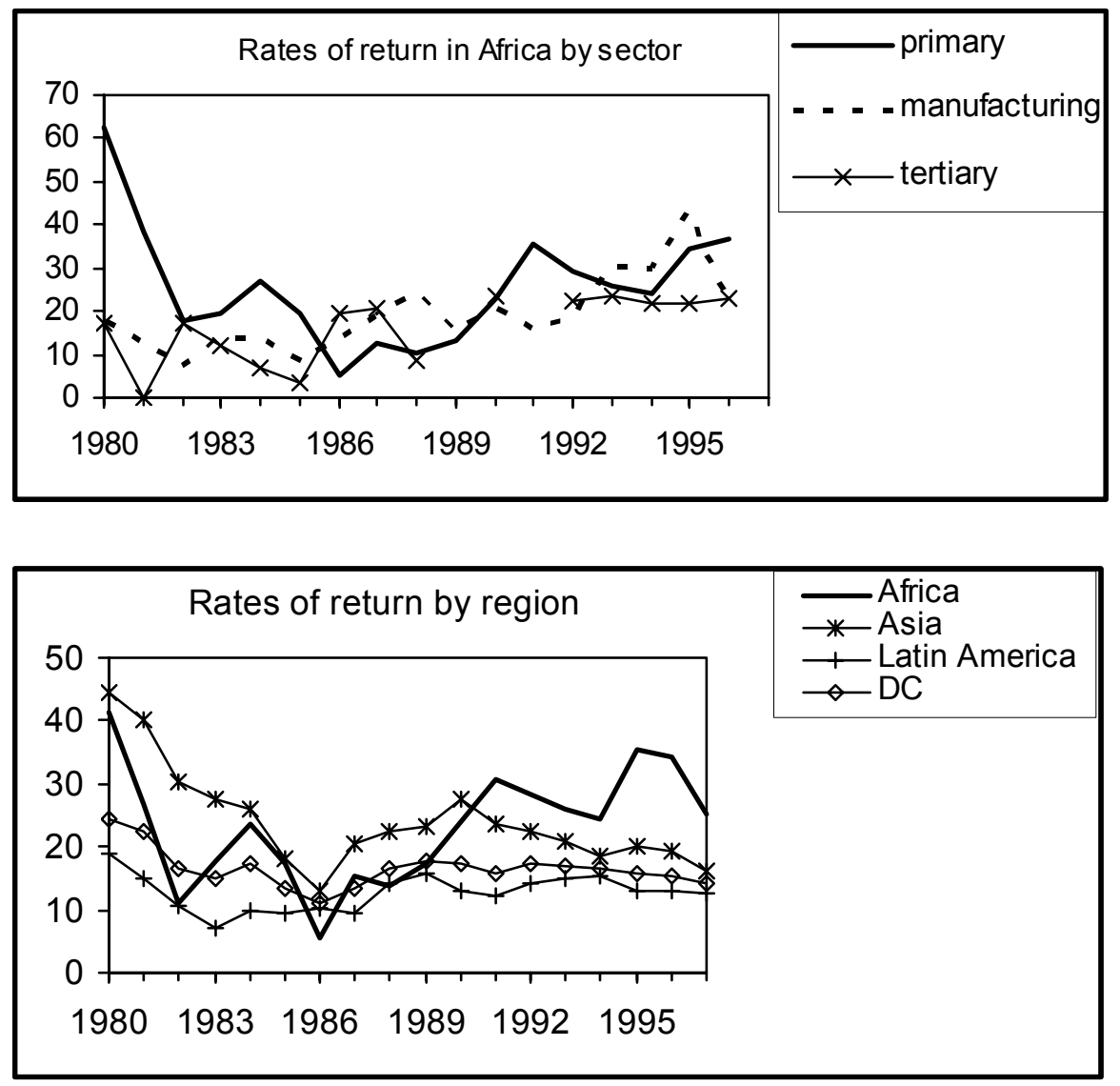

Sources: UCTAD (1995). FDI in Africa; UNCTAD, World Investment Report 1998.

* The rate of return is net income of US foreign affiliates divided by the average of the beginning-of-year and end-of-year FDI stock.

$\mathrm{DC}=$ Developing Countries. 
Figure 3: Distribution of FDI inflows in Africa (without South Africa), 1981-1998

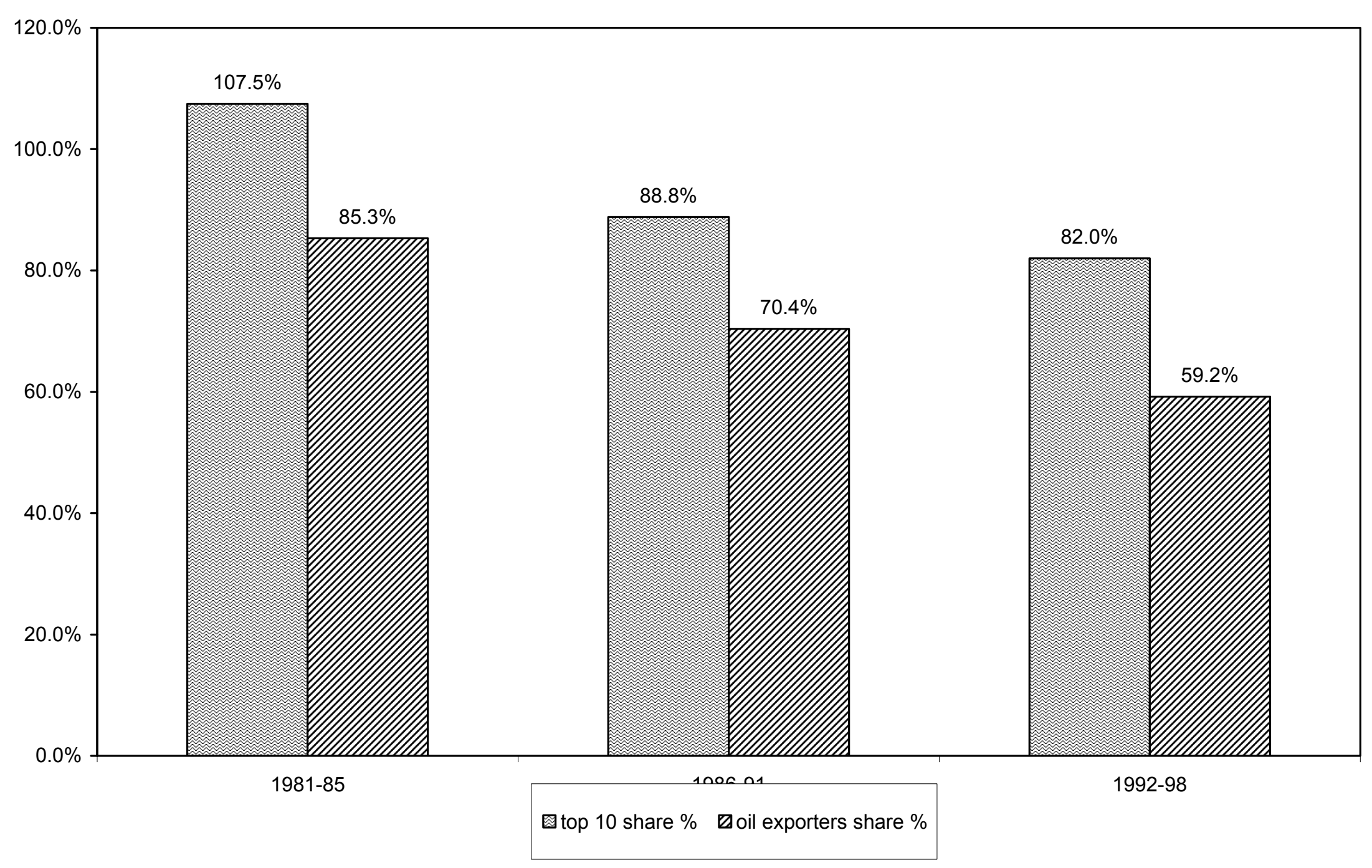


Figure 4: FDI inflows in selected African countries, 1986-1999 (million constant 1995 \$)
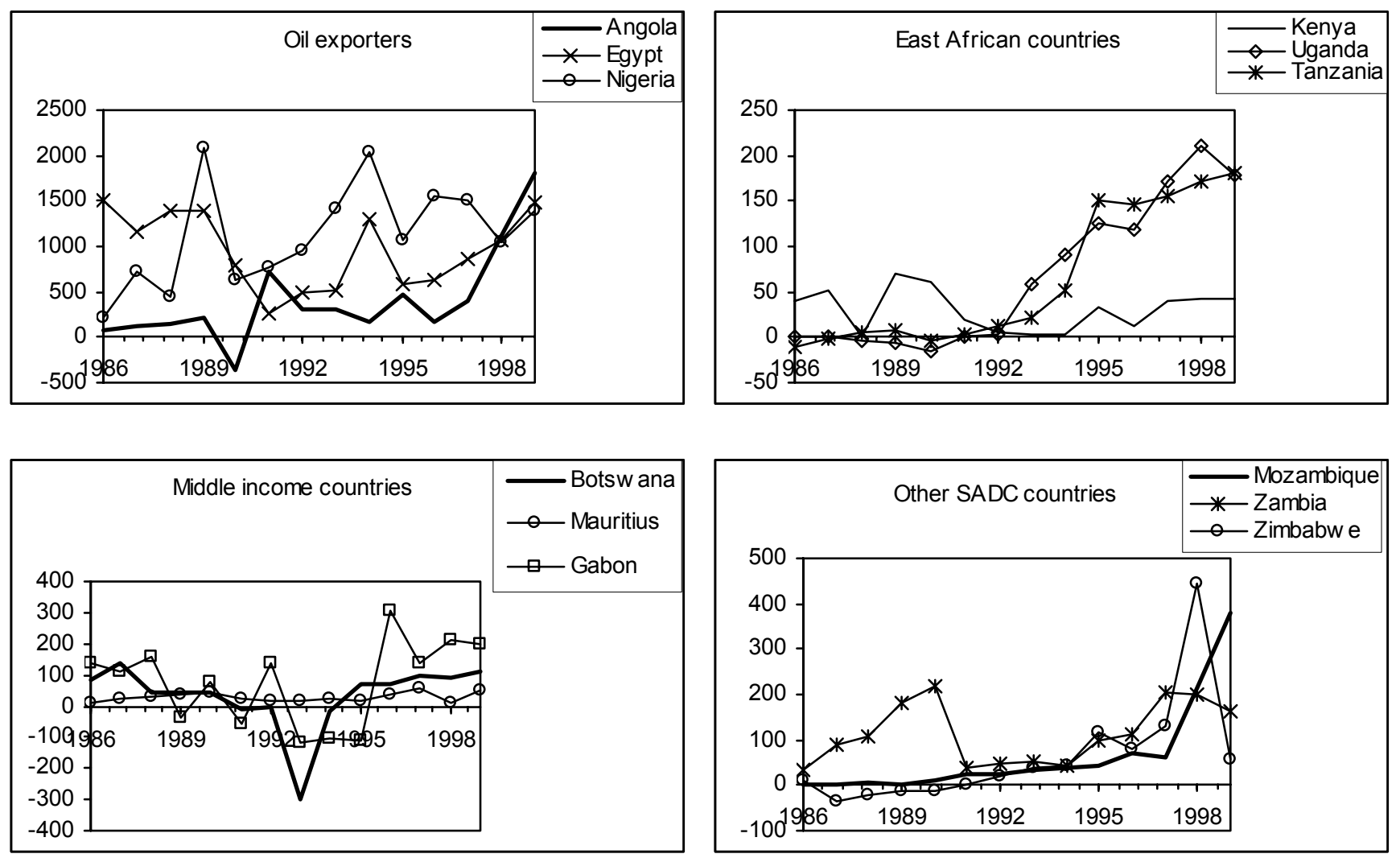

Source: UNCTAD, World Investment Report (various issues, 1992 to 2000).

Nominal values are deflated to real values using the US PPI index (base 1995=100). 
Figure 5: Exchange rate regime transition in Africa and other regions from 1991 to 1999 (number of countries by regime and share in the sample)
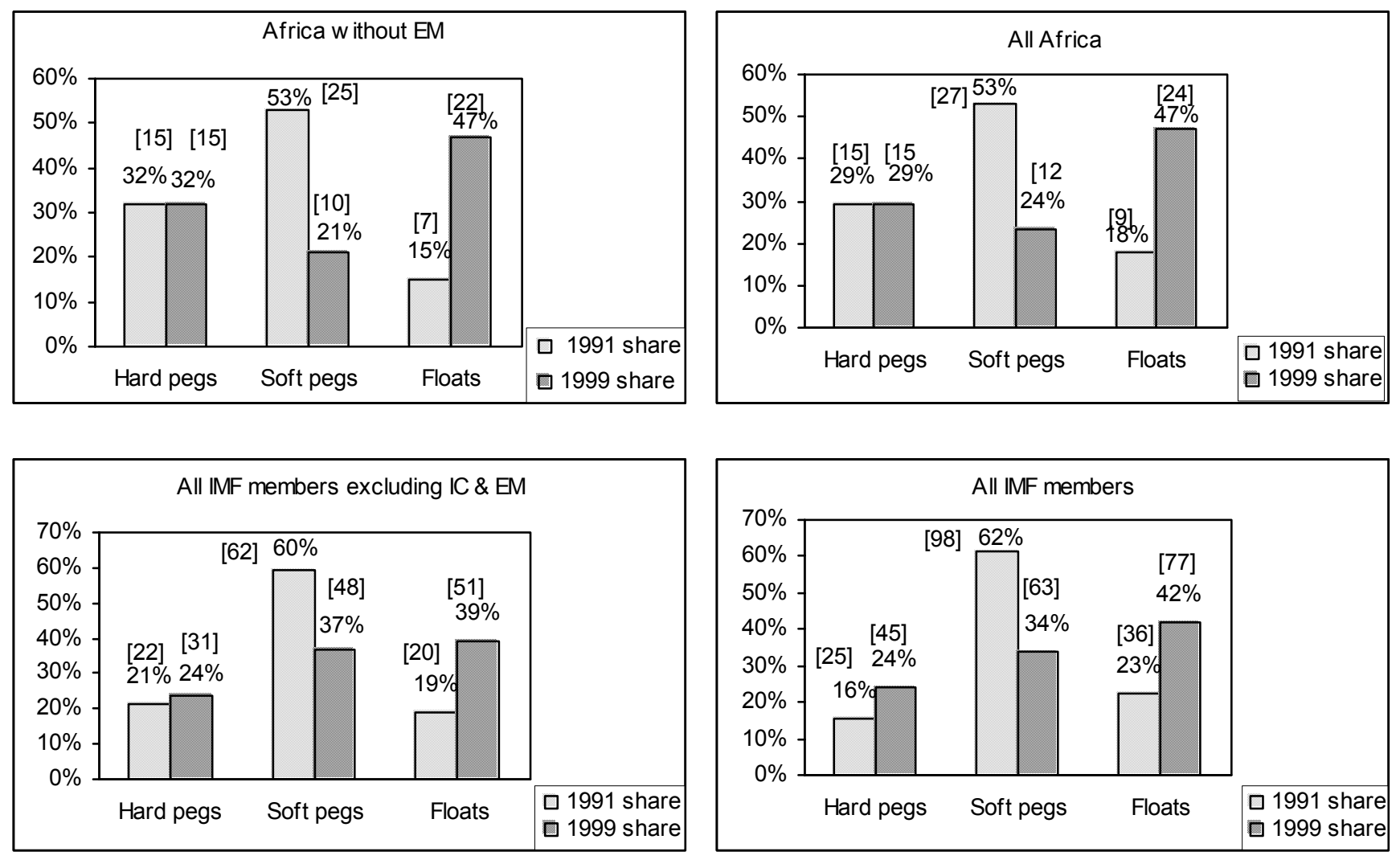

Source: Fisher, S. (2001) "Exchange rate regimes: Is the bipolar view correct?", Journal of Economic Perspectives, 15(2): 3-24.

Notes: $\mathrm{EM}=$ emerging markets; $\mathrm{IC}=$ Developed Countries.

The number of countries in the corresponding exchange rate regime category is given in brackets. 


\section{APPENDIX \\ Capital account and foreign exchange regimes: Recent developments in some African countries}

\section{Egypt}

\section{a. Capital flows}

Egypt experienced a surge in capital inflows over the 1990s decade, which were motivated primarily by the increased confidence by foreign investors in the Egyptian economy following economic reform. Noteworthy developments include successful fiscal adjustment and the curbing of inflation, which, under a relatively liberal capital account regime contributed to this surge of capital inflows.

However, the surge in capital inflows has raised some concerns with regard to their impact on the stability and the performance of the economy, especially because high capital inflows cause pressure on the exchange rate, which undermines export performance.

\section{b. Exchange rate regime}

The exchange rate regime in Egypt has undergone significant shifts in the early 1990s. Starting in 1969, Egypt instituted a system of multiple exchange rates and maintained an "official" parallel market to attract workers' remittances and encourage tourism. The exchange rate policies pursued in the 1970s and the 1980s resulted in substantial appreciation of the Egyptian pound and undermined export competitiveness.

As part of the reform program, the government established a free market for foreign exchange for current account transactions in 1991, and eased capital account restrictions further in 1992. The real exchange rate continued to appreciate after 1991, partly as a result of nominal appreciation and partly as a result of the differential in inflation between Egypt and its trading partners (see Subramanian and Handy 1997 and Mongardini 1998). There is no evidence to suggest that the real appreciation reflected productivity gains. The country did not experience any improvement in trade performance. In fact non-oil exports declined at the end of the decade.

The appreciation of the Egyptian pound may continue in the future if capital inflows continue (keeping reserves high). Debt forgiveness and debt rescheduling may further improve the external reserves position, thus contributing to further real exchange rate appreciation.

\section{c. The financial system}

The Egyptian stock market is one of the oldest stock markets in the world. However, the stock exchange was largely dormant for over four decades following the policy shifts of the 1950s with the nationalization of industry and the adoption of central planning (Mecagni and Sourial 1999). The 1990s saw a marked expansion of the stock market, with an increase in the number of listed companies, market capitalization, and liquidity. Much improvement is still needed, however, to provide an environment that allows the capital market to channel and allocate resources efficiently, especially by enforcing information disclosure by firms and by strengthening the legal environment to protect creditor and investor rights. 


\section{Kenya}

\section{a. Symptoms of a crisis at the end of the 1980s}

Towards the end of the 1980s (especially starting in 1987), the Kenyan economy showed signs of a pending crisis. Real GDP slowed down from an already weak position. The budget deficit was high (about 6\% of GDP in 1987), and inflation rose from 4.8\% in 1986 to $7.6 \%$ in 1987 and continued to climb in the following years. At the same time, the policy stance was characterized by high regulation in foreign exchange markets, trade, and the financial system (differential credit ceilings, interest rate controls, and political intrusion in credit allocation). By the end of the decade, it was clear that in the absence of major reforms, economic collapse was inevitable. Here, only policy reforms in the areas of foreign exchange markets, current and capital accounts are summarized (see Ariyoshi et al. 2000 and Krichene 1998 for further details on recent policy reforms in Kenya).

\section{b. Recent important policy reforms in exchange rates, current account and capital account} - In 1989, Kenya began the process of liberalization of the financial system. Interest rate ceilings were gradually removed and interest rates fully liberalized by 1991. - In 1991, the liberalization of current and capital accounts was initiated with the introduction of "foreign exchange bearer certificates of deposits", which could be used in current and capital account transactions. These certificates were available for residents and nonresidents, they were freely traded in the secondary market, and redeemed at the central bank at the face value.

- Since 1991, some companies were allowed to hold foreign currency-denominated bank accounts abroad and domestically. Banks were allowed to conduct transactions in foreign exchange directly. Forward foreign exchange contracts were allowed at market rates albeit with some restrictions on the amount and the term.

- In 1993 ( $4^{\text {th }}$ quarter), the exchange rate regime shifted from a currency composite peg to an independently floating regime.

- In 1994, the Kenyan shilling became fully convertible.

- In 1995, all remaining exchange controls were removed. Also removed were restrictions on purchases of shares and government securities by nonresidents.

\section{c. Crisis amidst (speedy) liberalization}

Despite the liberalization efforts, the crisis that had started at the end of the 1980s continued throughout the 1990s. Inflation rose from $19.8 \%$ in 1991 to $45 \%$ in 1993 . It started declining in 1994 and dropped to single-digit levels again later in the decade (5.8\% in 1998).

Due to the continued deterioration of the economic situation, the government moved in, tightening monetary policy and fiscal policy. However, the tight policy stance may have contributed to suffocating an already weak economy by undermining domestic demand. Liberalization in Kenya did not achieve the intended objectives of stabilizing the economy and boosting production. An IMF study concludes that "rapid and wide-ranging liberalization in the context of continued major macroeconomic imbalances may have increased the country's vulnerability to capital flows by providing legal channels for capital flight (the latter reflecting both a deterioration in private sector confidence and corruption)" (Ariyoshi et al. 2000: 67). 


\section{Malawi}

\section{a. Exchange rate and capital account regimes}

Until May 2000, Malawi had actively managed its foreign exchange markets, which resulted in large depreciation of the kwacha as well as severe distortions of economic incentives (IMF 2001). The country data indicate large depreciations of the kwacha, especially in 1994, in 1998 (by 40\%), and in 2000 (by another 40\%). Even in periods of relative stability of the exchange rate (between 1994 and 1998), high inflation rates led to substantial real depreciation of the currency.

May 2000 marked a major policy shift, when the central bank stopped quoting an explicit exchange rate and reduced substantially its intervention for exchange rate determination purposes, making the exchange rate fully flexible.

Since 1995, Malawi has moved towards liberalization of capital account transactions. For example, nonresidents are allowed to repatriate investment proceeds without restrictions (only registration for statistical purposes is required).

\section{b. Implications of membership in regional arrangements}

Malawi is a member of various regional bodies, including the SADC, COMESA, and the Cross-Border Initiative in Eastern and Southern Africa, or CBI (see Fajgenbaum 1999). Malawi is one of the best performing participants in the CBI and COMESA with respect to trade liberalization. One important issue is that membership in various regional bodies can produce distorted economic incentives and create administrative problems when obligations under the various bodies are inconsistent.

A structural constraint for Malawi is its weak productive capacity, which limits the gains from multilateral arrangements. Another important constraint is poor development of its financial system. The banking sector is heavily concentrated, with the two largest banks accounting for 90 percent of deposits. These banks lend to a limited number of companies, many of which own large shares of the banks' capital. This promotes insider lending, which results in an inefficient allocation of credit.

\section{Nigeria}

\section{a. Exchange rate regime}

Over the years, Nigeria applied a variety of foreign exchange arrangements, including fixed official exchange rates, market-determined exchange rates, dual systems of fixed official rates, and rates based on interbank exchange (IMF 1998). Before 1986 (the beginning of structural adjustment), the official rate was fixed without any link to the market rate or inflation, resulting in a high premium. After 1986, the government pursued a de facto indexation of the official exchange rate by adjusting the official exchange rate in response to changes in parallel market to prevent the premium from being too large. The evidence shows that the official and parallel exchange rates moved together after 1986 (Azam 1999).

With the "abandonment" of the adjustment program in 1994, the Nigerian government reinstated - among other controls - foreign exchange controls with an artificially fixed exchange rate. However, by the end of 1994, it was clear that attempts to stabilize the Naira by administrative means had failed. In 1995, the government made a turnaround, resuming the economic liberalization program. Since then the government has pursued policies aimed at 
allowing the exchange rates to reflect market conditions while using monetary policy to contain pressures on foreign exchange markets. In January 1999, the government abolished the official exchange rate (fixed at 22 Naira per dollar since 1993), and the Central Bank of Nigeria (CBN) gradually shifted its intervention from weekly allocation of foreign exchange through the Autonomous Foreign Exchange Market (AFEM) to exclusive reliance on continuous buying and selling in the Interbank Foreign Exchange Market (IFEM). This has eliminated the multiple exchange rates arising from the spread between the rates in the two markets.

\section{b. Liberalization of the capital account}

Since 1995, Nigeria has embarked on a process of liberalization of controls of capital movements. The following are some of the recent measures intended to encourage foreign capital inflows:

- The Foreign Exchange Monitoring and Miscellaneous Provisions Decree of July 1995 (retroactively effective January 1995) permitted individuals and businesses to invest in any firm through an accredited dealer in the AFEM.

- Guaranteed transferability in convertible currency for dividends, profits, debt service, and proceeds of whole or partial sale or liquidation of initial investment.

- Nationals are allowed to invest in securities abroad, provided proper documentation. However, nationals are not permitted to simply make deposits abroad, as officials are concerned that this may be a conduit for capital flight.

- Earlier "indigenization" measures that required majority Nigerian ownership of foreign enterprises have been abolished. There are no limits to foreigners' participation in any sector of the economy, except for crude oil and gas.

The authorities still face two interrelated and serious issues, namely high debt burden and capital flight. There is evidence of progress in economic reform, which will contribute to improving the overall macroeconomic environment. The country has especially embarked on a comprehensive reform program of the financial system aimed at strengthening the regulatory and supervision framework (e.g., higher independence of the CBN) and improving the stability of the banking sector (through enforcement of capital adequacy rules and systematic monitoring of banks). These measures, coupled with improvements in political stability, are likely to improve investor confidence, which will attract more capital into the country.

\section{South Africa}

\section{a. Turbulence in financial markets and foreign exchange markets}

The South African foreign exchange market and the financial system suffered the effects of the Asian financial crisis in mid-1998. Deterioration in investor sentiment caused substantial capital outflows and a depreciation of the Rand. The authorities responded by tightening monetary policy and by intervening in the foreign exchange market (IMF 2000). The financial turbulence receded at the end of 1998 and the South African Reserve Bank (SARB) allowed interest rates to decline. Low inflation expectations and prudent fiscal policy contributed to rejuvenating market confidence, causing a substantial return of international capital.

\section{b. Liberalization of the capital account}

Since 1994, the South African government committed to progressively abolishing controls

on capital account transactions. The liberalization covered transactions by nonresidents as well as 
residents, banks and nonfinancial firms, private and public enterprises, and private individuals. Some of the important changes since 1995 are the following:

- Dismantlement of restrictions on capital account and foreign exchange transactions by residents and nonresidents. Nonresidents were allowed to purchase shares, bonds, and other assets, and to repatriate dividends, interest receipts, profits as well as initial investment capital with little or no restrictions.

- Restrictions on exchange transactions by residents were substantially relaxed. While capital and current account transactions by residents are subject to quantitative restrictions, the quantitative caps have been progressively raised, and some have been abolished.

- Note, however, that the authorities maintain prudential regulation on foreign exchange by authorized dealers with no quantitative limits.

- Investment abroad by residents is allowed within some limits. For corporations, the limit is R250 million for investment within the SADC region (no limits for Namibia, Lesotho, and Swaziland, which are member of the Common Monetary Area) and R50 million elsewhere. Institutional investors are allowed to invest up to $15 \%$ of their assets abroad. Private individuals can invest up to R750,000 abroad.

\section{c. Foreign exchange policy: the "forward Book"}

The SARB has intervened in the foreign exchange market since the 1960s. The Bank has often maintained a large net open forward position (NOFP) whereby the Bank's forward US dollar liabilities exceed its forward dollar assets. The official objective of this policy is to absorb speculative pressures on the Rand, preventing sharp depreciations and mitigating the increases in the interest rate. The objective is not to defend a predetermined value of the Rand but to ease the (market-driven) adjustment of the exchange rate.

The experience of the 1990s suggest that the effectiveness of the SARB's intervention in the foreign exchange market in dampening pressures on the exchange rate was minimal and shortlived at best. In contrast, the evidence tends to support the view that high NOFPs lead to higher risk premia on investment in South Africa, as the market calls into question the ability of the SARB to sustain a large uncovered forward book.

\section{Uganda}

\section{a. Exchange rate regime}

The Ugandan government has committed to moving toward liberal foreign exchange and trade regimes. In particular, the government committed to not resisting fluctuations in the exchange rate due to changes in economic fundamentals. It is committed to supporting liberalization of the foreign exchange regime with appropriate fiscal and monetary policies. Recently the Ugandan shilling has been relatively more stable compared to the 1980s and early 1990s and compared to neighboring countries (Krichene 1998).

\section{b. Promoting a capital-friendly environment}

The Ugandan government has been noted for its commitment to pursuing macroeconomic policy reforms (especially fiscal and monetary policies). This will allow the government to establish policy credibility and achieve macroeconomic stability, which attracts new private foreign capital. The government also has pursued policies aimed at strengthening the financial system, including privatization of state-owned banks, enhancing banking supervision and regulation 
(including granting increased autonomy to the central bank), restructuring and recapitalization of weak banks, and the establishment of capital market infrastructure. Evidence of credible commitment to economic reform and improvement in the macroeconomic environment will increase investor confidence and stimulates capital inflows.

\section{The CFA zone}

\section{a. Origins}

The CFA zone is a creation of the political and economic relations between France and its former West African and Central African colonies. In the 1930s and 1940s, France established currencies in its colonies that were pegged on the French franc (FF). At the end of the second world war, these currencies were consolidated into the Franc des Colonies Françaises d'Afrique (thus CFA). Until the end of colonization, the currency was issued by the Caisse Centrale de la France d'Outre Mer. After independence, the two regional central banks of the CFA zone, the Banque Centrale des Etats de l'Afrique de l'Ouest (BCEAO) and the Banque des Etats de l'Afrique Centrale (BEAC) took over the issuance of the CFA.

The current membership of the CFA zone comprises 14 countries, including 12 former French colonies and 2 new members, Equatorial Guinea (since 1985) and Guinea-Bissau (since 1997). The zone comprises two regions: eight west African states (Benin, Burkina-Faso, Côte d'Ivoire, Guinea-Bissau, Mali, Niger, Senegal, and Togo) and six central African states (Cameroon, the Central African Republic, Chad, the Republic of Congo, Equatorial Guinea, and Gabon). The first group of countries belongs to the West African Monetary Union (WAMU) and the second belongs to the Central African Monetary Area (CAMA).

\section{b. Exchange rate and monetary arrangements}

The two regional central banks operate independently and issue two separate CFA currencies: the franc de la Communauté Financière de l'Afrique and the franc de la Coopération Financière Africaine. But since the two currencies have the same parity to the FF, they are equivalent for all practical purposes and the zone is in fact a common currency area. Any decision to change the parity of the currencies requires the unanimous support of all members of the entire zone.

The parity of the CFA to the FF was established in October 1948 at 0.5 CFA per FF. However, in 1968 the parity was adjusted following the introduction of a new FF equivalent to 100 of old FF. The value of the CFA relative to the FF did not change, but its absolute value was raised to $50 \mathrm{CFA}$ per FF. Following continued deterioration of economic conditions in the 1980s and early 1990s, the CFA, which had been overvalued for years, was finally devaluated by 50\% in February 1994.

The CFA is fully convertible and there is free capital mobility between the two regions and France. Full convertibility of the CFA is guaranteed by the French Treasury, rather than the Central Bank of France. Therefore, the arrangement is of a budgetary rather than monetary nature. This feature facilitated the shift of the parity from the FF to the euro at the creation of the EMU, as it did not require the approval by other members of the EMU. This shift has left the operating structures of the CFA zone and the relationships between the group and France fundamentally unchanged. The current fixed rate is $100 \mathrm{CFAF}$ per 0.8385 euro. For further details on the CFA zone and the 
implications of the EMU, see, among others, Hadjimichael and Galy (1997) and Honohan and Lane (2000).

Under the fixed exchange regime zone member countries have been able to maintain inflations rates that are lower than other comparable sub-Saharan African countries. However price stability was achieved at significant costs. The inability to adjust the exchange rate has resulted in higher sensitivity of economic growth to real shocks, especially terms-of-trade fluctuations. Most observers conclude that CFA zone countries would have been better off having flexibility to use exchange rate adjustments in the presence of external shocks (see Savvides 1996). 